\title{
Framework for Climate Change Adaptation of Agriculture and Forestry in Mediterranean Climate Regions
}

\author{
André Vizinho ${ }^{1, *} \mathbb{C}$, David Avelar ${ }^{1}$, Cristina Branquinho ${ }^{1} \oplus$, Tiago Capela Lourenço ${ }^{1} \mathbb{D}$, Silvia Carvalho ${ }^{1}$,

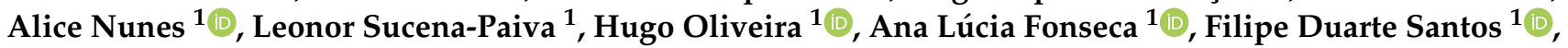 \\ Maria José Roxo ${ }^{2}$ and Gil Penha-Lopes ${ }^{1}$
}

1 Centre for Ecology, Evolution and Environmental Changes (ce3c), Faculdade de Ciências da Universidade de Lisboa, Campo Grande, Bloco C2, Piso 5, 1749-016 Lisboa, Portugal; dnavelar@fc.ul.pt (D.A.); cmbranquinho@fc.ul.pt (C.B.); tcapela@fc.ul.pt (T.C.L.); sccarvalho@fc.ul.pt (S.C.); amanunes@fc.ul.pt (A.N.); mlpaiva@fc.ul.pt (L.S.-P.); hfoliveira@fc.ul.pt (H.O.); alfonseca@fc.ul.pt (A.L.F.); fdsantos@fc.ul.pt (F.D.S.); gppenha-lopes@fc.ul.pt (G.P.-L.)

2 Faculdade de Ciências Sociais e Humanas, Universidade Nova de Lisboa, Avenida de Berna, 26-C, 1069-061 Lisboa, Portugal; mj.roxo@fcsh.unl.pt

* Correspondence: andrevizinho@fc.ul.pt; Tel.: +351-965615379

check for

updates

Citation: Vizinho, A.; Avelar, D.; Branquinho, C.; Capela Lourenço, T.; Carvalho, S.; Nunes, A.;

Sucena-Paiva, L.; Oliveira, H.; Fonseca, A.L.; Duarte Santos, F.; et al. Framework for Climate Change Adaptation of Agriculture and Forestry in Mediterranean Climate Regions. Land 2021, 10, 161. https:// doi.org/10.3390/land10020161

Academic Editor: Josep Maria Espelta Received: 8 December 2020

Accepted: 1 February 2021

Published: 5 February 2021

Publisher's Note: MDPI stays neutral with regard to jurisdictional claims in published maps and institutional affiliations.

Copyright: (c) 2021 by the authors. Licensee MDPI, Basel, Switzerland. This article is an open access article distributed under the terms and conditions of the Creative Commons Attribution (CC BY) license (https:/ / creativecommons.org/licenses/by/ $4.0 /)$.

\begin{abstract}
Planning the adaptation of agriculture and forestry landscapes to climate change remains challenging due to the need for integrating substantial amounts of information. This information ranges from climate scenarios, geographical site information, socio-economic data and several possible adaptation measures. Thus, there is an urgent need to have a framework that is capable of organizing adaptation strategies and measures in the agriculture and forestry sectors in Mediterranean climatic regions. Additionally, this framework should provide a cause effect relation with climate vulnerability to adequately support the development of adaptation planning at municipal and local (farm) level. In this context, we propose to test and evaluate a framework for climate adaptation of the agriculture and forestry sectors, based on the local causal-effect relation between adaptation strategies and measures and the level of vulnerability reduction achieved for Mediterranean areas. The framework was developed based on the combination of the DPSIR (Driving forces, Pressures, State, Impacts, Responses) and Vulnerability frameworks and reviewed 162 practical adaptation measures, further organized into strategies, complemented by a set of efficacy indicators. The framework was tested with 70 stakeholders in six stakeholder workshops for the planning of two farms and one municipal climate adaptation study, that are now in actual implementation and monitoring. The framework is composed by a set of eight adaptation strategies in which adaptation measures are clustered and assessed using efficacy indicators. In the evaluation of the adaptation framework, $96 \%$ of stakeholders considered its content as good or very good and $89 \%$ considered the final outcomes as good or very good. Finally, the framework was also used to assess and compare the adaptation strategies and measures presented in the climate adaptation plans of the three case studies. On average, $52.2 \%$ of the adaptation measures selected by the three case studies are dedicated to Ecosystem Resilience, 30.9\% to Adaptive Capacity, 9.1\% to Microclimates, 7.4\% to Protection, and $0.3 \%$ to Mitigation strategies. This framework was considered effective in supporting adaptation planning at farm and municipal levels and useful to assess and compare adaptation plans in the frame of vulnerability reduction. Future studies can further contribute to support adaptation planning in these sectors by using, developing and streamlining this framework to additional and different socio-ecological contexts.
\end{abstract}

Keywords: climate change adaptation; landscape planning; farm adaptation; municipal adaptation; agroforestry; efficacy; decision making 


\section{Introduction}

The Paris Agreement sets out a target to limit the increase in global mean temperature to well below $2{ }^{\circ} \mathrm{C}$ above pre-industrial levels and to pursue efforts to limit that increase to $1.5^{\circ} \mathrm{C}$ [1]. However, the latest projections, according to the current policies, point to substantially higher levels of warming unless radical actions to cut greenhouse gas (GHG) emissions are set in motion [2]. Scenarios of climate change for the Mediterranean region until the end of the XXI century [3] project an increasing suite of climate risks, including loss of ecosystem services, desertification and land degradation, migration of animals and the degradation of extensive areas of forests and agroforestry systems [4]. These cause severe economic, social and environmental costs [5-7] which make climate adaptation essential, particularly in Mediterranean Climate Regions [8,9].

Planning for climate change adaptation must bridge across science and society, integrate complexity and deal with the challenge of managing and communicating complexity and uncertainty [10-14]. The uncertainty about the future climate comes not only from the GHG emission models but also from climate model limitations. Uncertainty increases with the downscaling of global and regional climate models to local models, largely due to variations in topography, soil, winds, water, ecosystem type, etc. $[13,15,16]$.

In the sector of agriculture and forestry adaptation measures may focus on: (i) the crop (the adaptation may consist of changing or improving the crop/species/variety in itself); (ii) the cropping system (includes the management practices and techniques as well as crop rotation and timings); and (iii) the farming system (includes the farmer and, therefore, the adaptation capacity, the market, regulation, economic incentives, protection mechanisms and information) [8]. Thus, adaption in this sector requires knowledge on the climate sensitivity of each crop, species and variety under different soil conditions (e.g., water retention, nutrients, organic matter and structure, among others), exposure to climate variables throughout the year (e.g., solar radiation, humidity, rainfall, temperature), interactions with other species (e.g., crops, biodiversity, pests), land uses and the interdependency with the agricultural techniques used $[17,18]$.

Although, adaptation measures can be effective for several crops, beyond certain thresholds of climate change, adaptation measures must be complemented with more systemic changes such as diversification of production systems and livelihoods, that increases system resilience [19]. These more systemic adaptation actions address other climate risks such as changes in markets, which will increase due to the impacts in agriculture productions in many regions [19]. To facilitate the integration of this complexity in adaptation planning, Howden et al. conclude that "a crucial component of this approach is the implementation of adaptation assessment frameworks that are relevant, robust, and easily operated by all stakeholders, practitioners, policymakers, and scientists" [19]. In addition, due to the risk of maladaptation, several studies point out a clear need for adaptation frameworks that can bring, to the top of the planning agenda, the full overview of the adaptation strategies, namely in combination with mitigation [20-22]. The need for such a framework was also identified in our participatory research, as we propose stakeholders to analyse and discuss the adaptation measures for the agriculture and forestry of the region in study. The vast list of adaptation measures and, most importantly, the degree to which some fit in others or are effective by addressing different aspects of vulnerability, showed the stakeholders and the authors of this study the need for a sector specific adaptation framework. After reviewing the adaptation frameworks for agriculture and forestry we found no framework that is capable of organising the hierarchy of the adaptation strategies and measures in a robust structure that is based on cause effect relations and, is, at the same time, easily used to support real-world decision making (see Section 1.1).

The problem that this study aims to address is thus the lack of an adaptation framework that can adequately support the adaptation planning in the sector of agriculture and forestry, namely at the farm and local spatial planning level. To address this problem, we need a conceptual, hierarchical, causal, and functional organization of adaptation strategies and measures. Furthermore, in order to assess, evaluate and choose adaptation measures 
for specific agriculture and forestry contexts a set of indicators of efficacy is required. The aim of this study is to propose, test and evaluate a framework for climate adaptation of the agriculture and forestry sectors, that is able to support farm-level and municipal-level adaptation planning in Mediterranean areas.

\subsection{Adaptation Frameworks}

The Driving forces, Pressure, State, Impact, Responses (DPSIR) framework [23,24], known and used for a long time in the analysis of environmental problems, defines a chain of causal links that help to decide if we want to act on the causes or on the consequences of an impact. It starts with Driving forces (e.g., human activities and, in this case, greenhouse gases emissions), followed by Pressures (e.g., climate variables, emissions, waste, pollution), State (e.g., physical, chemical, biological, ecological elements and functioning of the system) and Impacts (on ecosystems, health, functions), eventually leading to Responses (in this case, adaptation measures). While this framework continues to provide a cause effect rationale for analysing environmental problems and responses, several Climate Change Adaptation (CCA) frameworks have, meanwhile, been developed to support adaptation planning. Bours et al. have reported and analysed 16 of these frameworks that apply to different sectors and scales, some more theoretical and others more practice oriented. Despite the large number of frameworks, in their analysis they still conclude that "the evidence base informing CCA is still fragmentary and nascent" and that "they have shown only moderate practical effect in reducing vulnerabilities" [25]. Regarding indicators, these authors state that an effort must be made to harvest innovative indicators more directed to applied research [25].

The Vulnerability Framework [26] defines adaptation as the actions that reduce the vulnerability to climate change potential impacts. The potential impacts are a function of the exposure to climate variables and the sensitivity of the system. The vulnerability is a function of the potential impacts with the capacity to adapt. The UKCIP Adaptation Wizard is based on identifying present and future vulnerabilities, identifying criteria for decision making and then identifying and evaluating adaptation measures to reduce those vulnerabilities [25]. The Adaptation Pathways [27,28] uses the concept of tipping points when a certain adaptation action is no longer effective. When a tipping point is reached, another adaptation action must be implemented. In this framework, the adaptation pathways and tipping points map is only developed after the identification of the vulnerabilities and the identification and quantification of the efficacy of adaptation actions. Thus, to use this framework in agriculture and forestry sectors a comparison of the efficacy of adaptation measures must be available $a$ priori.

There are several other frameworks that, due to their nature, partially overlap with the objectives of the Climate Adaptation frameworks. The Disaster Risk Reduction (DRR) is a framework that focuses on extreme events like fires, droughts, storms, and floods, including therefore the impacts of climate change. Climate adaptation frameworks focus on changes in average values of precipitation and temperature and their distribution over time, which include extreme events [29].

\subsection{Adaptation Frameworks for Agriculture and Forestry Sectors}

In the context of agriculture and forestry, Mitter et al. [30] classified the process of adaptation into 3 types of implementation: (a) incremental, (b) systemic or (c) transformational separated. Robert et al. [31] draw attention to the temporal scale of adaptation and they found that $70 \%$ of the adaptation studies focus only in one of these time scales of adaptation (day, or season or long-term), highlighting the need to integrate these dimensions in a multi-temporal scale approach.

Some authors developed more specific frameworks for the agriculture and forest sector. Smit and Skinner [18] characterized the adaptation measures according to aim, timing and duration, scale, responsibility and form and organized adaptation measures into the following types: (i) technological developments; (ii) government programs and insurance; 
(iii) farm production practices; and (iv) farm financial management. On the other hand, Kurukulasuriya and Rosenthal [32] developed typologies more related to the time when the effects of the adaptation measures will be observed: (i) short term adaptations; (ii) long term adaptations; and (iii) adaptations irrespective of the temporal dimension of climate impacts. Hernández-Morcillo et al. [22], prioritized the agroforestry measures for adaptation and mitigation according to their perceived performance. Focusing on mitigation, they proposed several measures for sequestering carbon or reducing greenhouse gases, whereas focusing on adaptation they proposed measures for enhancing resilience or reducing threats.

The Mediterranean forest sector alone was already the object of different adaptation frameworks. Regato et al. [33] divided the adaptation measures by the typology of actions: (i) changes in tree species composition; (ii) conservation/restoration of biotic dispersal vectors; (iii) changes in silvicultural practices; (iv) changes in soil management practices; (v) changes in forestry guidelines; and (vi) landscape adaptation options. Vilà-Cabrera et al. [34] defined three general objectives for the adaptation of Mediterranean forests: (1) decrease disturbance risk; (2) increase resistance to disturbance and (3) promote recovery after disturbance. Furthermore, they defined five adaptation strategies: (a) reduction in stand density; (b) management of the understory; (c) promoting mixed forests; (d) changing species or genetic composition; and (e) promoting spatial heterogeneity at the landscape level.

The adaptation frameworks, classification objectives and components, previously presented and summarized in Table 1, show that none of the components or categories used to organize the adaptation measures are similar or integrate each other and, therefore, add complexity to the adaptation planner. Although relevant to understand and categorize adaptation actions in agriculture and forestry, they do not organize the adaptation measures in relation to vulnerability reduction. Instead, they organize the adaptation components in relation to: types of implementation (Mitter et al. [30]); temporal scale (Robert et al. [31]); aim, timing and duration, scale, responsibility and form (Smit and Skinner [18]); the time needed for effects to be observed (Kurukulasuriya and Rosenthal [32]); their perceived performance (Hernández-Morcillo et al. [22]); and the typology of actions (Regato et al. [33]) or general objectives (Vilà-Cabrera et al. [34]).

Table 1. Climate adaptation frameworks for agriculture and forestry. Each framework categorizes adaptation measures according to different classification objectives. The different components presented by the different frameworks, are shown in columns Component 1 to Component 6 and illustrate the complexity present in planning adaptation in this sector.

\begin{tabular}{|c|c|c|c|c|c|c|c|}
\hline $\begin{array}{l}\text { Adaptation } \\
\text { Framework }\end{array}$ & $\begin{array}{l}\text { Classification } \\
\text { Objective }\end{array}$ & Component 1 & Component 2 & Component 3 & Component 4 & Component 5 & Component 6 \\
\hline $\begin{array}{l}\text { Hernandéz- } \\
\text { Morcillo et al. } \\
\text { (2018) [30] }\end{array}$ & $\begin{array}{l}\text { Perceived } \\
\text { performance }\end{array}$ & $\begin{array}{l}\text { Mitigation } \\
\text { (sequestering } \\
\text { carbon and } \\
\text { reducing } \\
\text { green-house } \\
\text { gases) }\end{array}$ & $\begin{array}{l}\text { Adaptation } \\
\text { (enhancing } \\
\text { resilience and } \\
\text { reducing } \\
\text { threats) }\end{array}$ & - & - & - & - \\
\hline $\begin{array}{c}\text { Vilà-Cabrera } \\
\text { et al. (2018) } \\
{[34]}\end{array}$ & $\begin{array}{l}\text { Adaptation } \\
\text { Strategies }\end{array}$ & $\begin{array}{l}\text { Reduction in } \\
\text { stand density }\end{array}$ & $\begin{array}{c}\text { Management } \\
\text { of the } \\
\text { understory }\end{array}$ & $\begin{array}{l}\text { Promoting } \\
\text { mixed forests }\end{array}$ & $\begin{array}{l}\text { Changing } \\
\text { species or } \\
\text { genetic } \\
\text { composition }\end{array}$ & $\begin{array}{c}\text { Promoting } \\
\text { spatial } \\
\text { heterogeneity } \\
\text { at the } \\
\text { landscape level }\end{array}$ & - \\
\hline $\begin{array}{c}\text { Vilà-Cabrera } \\
\text { et al. (2018) } \\
{[34]}\end{array}$ & $\begin{array}{l}\text { Adaptation } \\
\text { Objectives }\end{array}$ & Decrease risk & $\begin{array}{l}\text { Increase } \\
\text { resistance }\end{array}$ & $\begin{array}{l}\text { Promote } \\
\text { recovery }\end{array}$ & - & - & - \\
\hline $\begin{array}{l}\text { Mitter et al. } \\
(2018) \text { [30] }\end{array}$ & $\begin{array}{c}\text { Types of } \\
\text { adaptation }\end{array}$ & Incremental & Systemic & Transformational & - & - & - \\
\hline $\begin{array}{l}\text { Robert et al. } \\
(2016)[31]\end{array}$ & $\begin{array}{l}\text { Temporal scale } \\
\text { of adaptation }\end{array}$ & Day & Season & Long-term & - & - & - \\
\hline $\begin{array}{l}\text { Regato et al. } \\
\text { (2008) [33] }\end{array}$ & $\begin{array}{l}\text { Adaptation } \\
\text { measures }\end{array}$ & $\begin{array}{l}\text { Changes in } \\
\text { tree species } \\
\text { composition }\end{array}$ & $\begin{array}{c}\text { Conservation/re } \\
\text { of biotic } \\
\text { dispersal } \\
\text { vectors }\end{array}$ & $\begin{array}{l}\text { toratipahges in } \\
\text { silvicultural } \\
\text { practices }\end{array}$ & $\begin{array}{c}\text { Changes in soil } \\
\text { management } \\
\text { practices }\end{array}$ & $\begin{array}{l}\text { Changes in } \\
\text { forestry } \\
\text { guidelines }\end{array}$ & $\begin{array}{l}\text { Landscape } \\
\text { adaptation } \\
\text { options }\end{array}$ \\
\hline
\end{tabular}


Table 1. Cont.

\begin{tabular}{|c|c|c|c|c|c|c|c|}
\hline $\begin{array}{l}\text { Adaptation } \\
\text { Framework }\end{array}$ & $\begin{array}{l}\text { Classification } \\
\text { Objective }\end{array}$ & Component 1 & Component 2 & Component 3 & Component 4 & Component 5 & Component 6 \\
\hline $\begin{array}{l}\text { Kurukulasuriya } \\
\text { and Rosenthal } \\
\text { (2003) [32] }\end{array}$ & $\begin{array}{l}\text { Temporal } \\
\text { frame of } \\
\text { adaptation } \\
\text { measures }\end{array}$ & $\begin{array}{l}\text { Short term } \\
\text { adaptations }\end{array}$ & $\begin{array}{l}\text { Long term } \\
\text { adaptations }\end{array}$ & $\begin{array}{l}\text { Adaptations } \\
\text { irrespective of } \\
\text { the temporal } \\
\text { dimension of } \\
\text { climate } \\
\text { impacts }\end{array}$ & - & - & - \\
\hline $\begin{array}{c}\text { Smit and } \\
\text { Skinner (2002) } \\
{[18]}\end{array}$ & $\begin{array}{c}\text { Adaptation } \\
\text { measures type }\end{array}$ & $\begin{array}{l}\text { Technological } \\
\text { developments }\end{array}$ & $\begin{array}{l}\text { Government } \\
\text { programs and } \\
\text { insurance }\end{array}$ & $\begin{array}{c}\text { Farm } \\
\text { production } \\
\text { practices }\end{array}$ & $\begin{array}{c}\text { Farm financial } \\
\text { management }\end{array}$ & - & - \\
\hline
\end{tabular}

\subsection{Mediterranean Drylands as a Study Area}

Our three case studies were developed in the south of Portugal, an area which is characterized by a Mediterranean climate, with class Csa (Mediterranean dry hot summer), which is, according to Köppen Geiger, a climate class that occupies vast areas of the Mediterranean basin and Mediterranean climate region [33,34]. According to Ramírez Villegas et al. [35], if climates are similar or analogue across space and/or time, then assessment of impacts and adaptation measures are also relevant across space and/or time. Climate scenario RCP 8.5 projects a significant decrease in rainfall and an increase in temperature and drought frequency, duration and magnitude over the Mediterranean region [36-39]. In both the south of Portugal and the Mediterranean region, some areas will change the climate classification from Csa to Bsh (Hot Semi-arid) in the climate change scenarios RCP 4.5 and RCP 8.5 [34,40]. Within these climate scenarios the fire risk will increase [41-43], and the biodiversity loss and habitat loss will increase, leaving several important plant and animal species, including trees, beyond their thresholds of survival [44-49]. This region which is, already in the present, very vulnerable to desertification [50,51] will reduce its productivity in agriculture and forestry, due to water scarcity, high temperatures, increased mortality and other impacts resultant from extreme events, such as droughts or heat waves [52-60]. Therefore, the future of agriculture and forestry in the region is, to a significant extent, threatened by climate change, making adaptation to a future climate essential in order to prevent severe ecological, social, and economic damage. The RCP 8.5 scenario for the period 2070-2100 projects a decrease in total accumulated annual precipitation in the Portuguese Alentejo region of around 20\%, from $630 \mathrm{~mm}$ to $519 \mathrm{~mm}$ and in its southern area (Baixo Alentejo) from $500 \mathrm{~mm}$ to $400 \mathrm{~mm}$ [42] (Figure 1). Cork oak (Quercus suber) and holm oak (Quercus ilex rotundifolia) are the main trees in this region, forming the typical savannahlike agroforestry system called montado, and their limits for acceptable productivity are $600 \mathrm{~mm}$ and $500 \mathrm{~mm}$ of annual rainfall, respectively [61,62]. Hence, the maintenance of the cork oak and holm oak Montado landscapes [63] is at high risk. Under the RCP 8.5 scenario, for the period 2070-2100, maximum temperature is expected to rise by $4^{\circ}$ to $5^{\circ}$ Celsius, the number of heat waves to go from the present 40 events per year to a future 160 events, and the number of days with frost to decrease from the observed 12 days per year to a future zero or one day [42]. Due to the increase in temperature, evaporation and evapotranspiration will be higher, meaning that the demand for water and irrigation will increase, while water reservoirs will have fewer reserves in the Iberian Peninsula [56,59]. Despite this challenge, the Portuguese national climate adaptation strategy for the agriculture and forestry sector states that the territory should aim to maintain its productivity and ecosystem services in the future [64], thus clarifying the general objective of adaptation. 


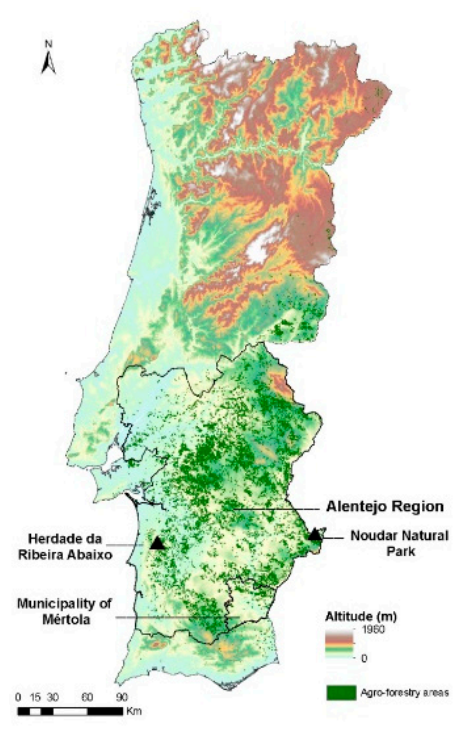

(a)

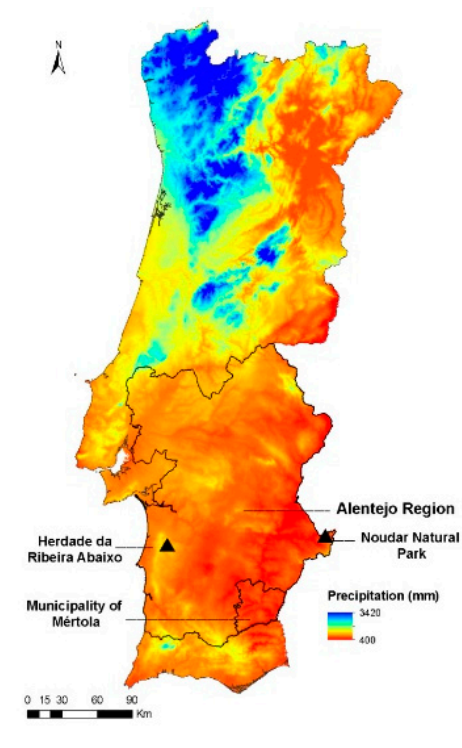

(b)

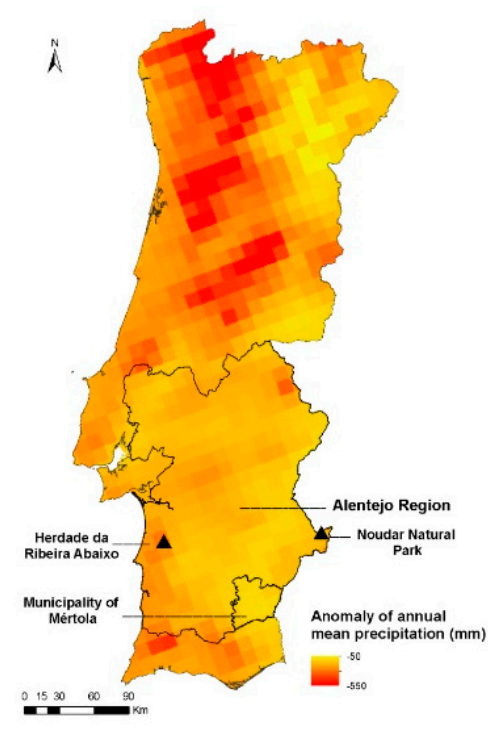

(c)

Figure 1. Map of Portugal with the location of the case studies of Mertola Municipality, Herdade da Ribeira Abaixo farm, and Herdade da Coitadinha/Natural Park of Noudar farm, within the study area of Alentejo region. (a) Altitude and agroforestry areas (from Corine land cover 2018); (b) observed annual mean precipitation for the period 1971-2000; (c) anomaly of annual mean precipitation for the period 2071-2100 under RCP8.5 scenario (datasets from IPMA, 2018).

Within this context, the present study was developed with the aim of supporting decision-making for climate adaptation of agriculture and forest landscapes in the dryland region of Mediterranean Europe, using a participatory-action-research (PAR) approach, namely at the case study region of Alentejo, in the south of Portugal. Its specific objectives are to (i) create a framework that organizes adaptation measures into strategies that are framed around their effect on climate vulnerability and to (ii) assess and compare the efficacy of adaptation measures for the reduction in vulnerability.

\section{Materials and Methods}

The methodology used to create such a framework was based on a Participatory Action Research (PAR) approach $[65,66]$ and started with identification and clarification of the problem that arose from participatory workshops for a given study area. After identifying the problem, the authors performed an extensive review of literature on adaptation frameworks for agriculture and forestry, in order to identify possible already existing solutions. This literature review, presented in the introduction, clearly shows, and reinforces, the need for such a framework. The next step of the methodology then consisted of collecting, assembling and analysing the data and information relevant to develop a proposal. This data consists, on the one hand, of the adaptation strategies and adaptation measures themselves. This methodological step is described in Section 2.3. Review of Adaptation Measures. On the other hand, the data consists on the conceptual and theoretic frameworks available to base such a proposal on. The development of a framework based on the existing conceptual frameworks is further described in Section 2.4. Finally, this framework supported the organization of indicators, based on literature review, as explained in Section 2.5. The framework was then tested in the adaptation planning of two farms and one municipal case studies, evaluated by the participating stakeholders (see Section 2.6) and discussed by authors in the present study.

\subsection{Study Area and Case Studies}

The study was developed in the Alentejo Region, south of Portugal, with a practical application in three case studies: (i) the adaptation plan for agriculture and forestry sectors in the municipality of Mértola (130,000 ha); (ii) the adaptation plans for the Montado 
agroforestry system in the Nature Park of Noudar/"Herdade da Coitadinha" farm (991 ha) and (iii) "Herdade da Ribeira Abaixo" farm (221 ha).

\subsection{Research Stages}

This study included three stages: (1) assessing the state-of-the-art of adaptation in order to create a list of measures for the adaptation to climate change of agriculture and forestry in the Mediterranean climatic region; (2) organizing measures into strategies creating a conceptual model based on cause effect relations, which can support decisionmaking for adaptation planning; (3) assessing the efficacy of adaptation measures.

\subsection{Review of Adaptation Measures}

To assess the state-of-the-art of adaptation measures and strategies for agriculture and forestry we implemented three methods of research. We conducted a literature review using google scholar with the keywords "adaptation", "agriculture", "forestry" and derivatives, browsing for adaptation strategies, measures, tools, and techniques for the sector. Furthermore, we looked at institutional websites $[1,67,68]$, institutional publications, such as National Adaptation Strategies and outcomes of projects of climate adaptation using a dedicated database [68]. After this analysis we implemented a stakeholder workshop, named "Participatory State-of-the-art on Adaptation in Agriculture and Forestry of the Alentejo region", in which 43 researchers, representatives of NGOs that develop adaptation projects and the National Agency for Environment, presented their work and developed a review of the climate impacts for the region and the adaptation measures of the national adaptation strategy, from the perspective of the region [69]. Furthermore, they identified demonstration sites and farms that could be interviewed to search for more adaptation measures. We then implemented 21 semi-structured interviews to farmers that were pointed out by the three main farming federations in Portugal (Confederação dos Agricultores de Portugal (CAP), Confagri and Confederação Nacional Agricultura (CNA)) as farmers that implement good practices and are considered innovative and leaders in their farming practices. In these semi-structured interviews, we asked farmers what adaptation measures they had already implemented and what adaptation measures they would like to implement in the future.

As a result, we compiled a list of 162 adaptation measures for agriculture, forestry, agroforestry, and pastoral activities in the region (see Appendix A). Afterwards, we organized another stakeholder workshop, with 13 farmers, 8 representatives of farmers' associations/cooperatives and 15 other stakeholders (expert members of NGOs of local development or environment, representatives of a public irrigation company, national agency of environment, regional agency for irrigation support, consultants and researchers), to develop a multi-criteria analysis of the adaptation measures [70]. In this workshop, we received clear feedback that the adaptation measures and strategies needed to be organized in a hierarchical structure of strategies, measures and techniques that would support more efficient and clearer decision-making, thus reinforcing the need for this study and framework.

\subsection{Developing the Framework for Adaptation in Agriculture and Forestry}

With the objective of organizing the measures into strategies using as a base the cause effect relations that reduce vulnerability to climate change, we used the theoretical framework of the Vulnerability Framework [26], combined with the DPSIR framework [23]. The DPSIR framework Driving forces, Pressure, State, Impact, Responses was originally created to "structure and organize indicators in a meaningful way" and is presently validated as a robust tool to structure and communicate complex human environment problems and responses but also to support decision making by providing alternative effective solutions, rather than presenting predetermined solutions [71]. The use of the DPSIR framework to support climate adaptation was discussed for the first time by Eisenack and Stecker [72]. These authors consider that its main strength in this context is its structure on bio-physical 
causality. Several authors discuss, on the other hand, that there is a bio-physical, but also social, vulnerability in the context of climate change. The vulnerability framework is based on the IPCC definition that climate vulnerability is a function (f) of exposure, sensitivity and adaptive capacity [26]. Adaptive capacity is the potential to reduce social vulnerability [72] and since this is a crucial aspect of climate vulnerability and adaptation, the DPSIR framework should be complemented with the vulnerability framework. The DPSIR framework was used in the past to support the climate vulnerability assessment and it was considered useful in "structuring the analysis of the linkages between cause effect relationship of vulnerability to climate change" [73].

By combining both in the analysis of the list of adaptation strategies and measures, we were able to obtain a clearer understanding of the hierarchy of adaptation strategies and the position of the different adaptation measures regarding their function in the vulnerability reduction objective (see Figure 2).

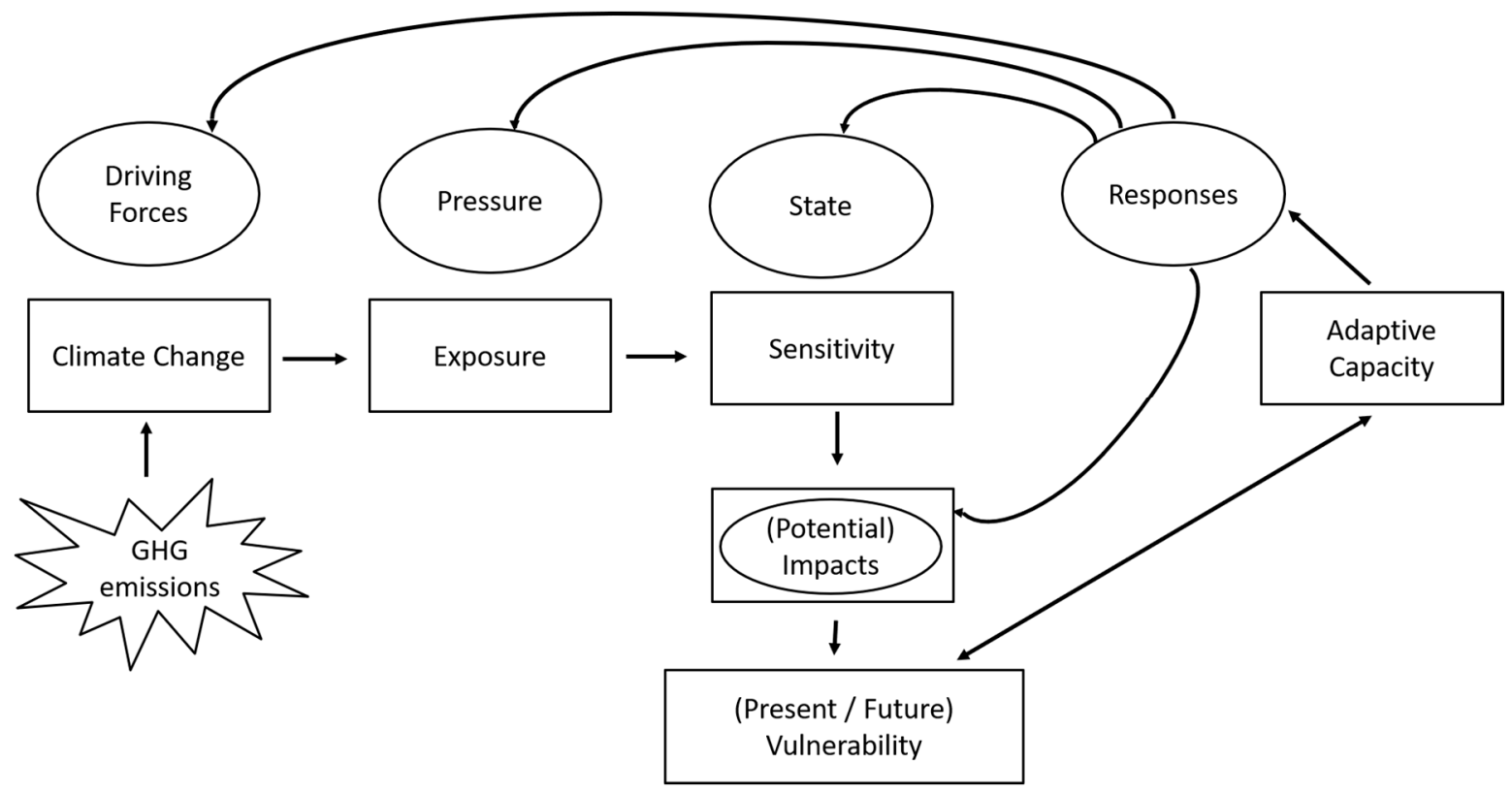

Figure 2. Combination of Vulnerability and DPSIR Framework. Items in rectangles refer to the Vulnerability Framework and items in circles refer to DPSIR Framework. Arrows indicate causal relations. GHG emissions are one of the main causes for Radiative Forcing and increase in Climate Change which is felt depending on the level of Exposure. Depending on the Sensitivity, this Exposure leads to Potential Impacts and Vulnerability, which is dependent on the Adaptive Capacity. Adaptive capacity can generate Responses that can be targeted at the origin of the problem, the Driving Forces and the Exposure/Pressure factors. Responses can improve the State of the ecosystem to make it less sensitive, or finally target the consequences, the Impacts on the system.

A conceptual framework proposal, naming strategies and organizing measures into strategies was then presented to colleagues and practitioners in meetings and seminars, feedback was received, and the framework was fine-tuned to be finally used to support decision-making in the adaptation planning of the three case studies. The adaptation planning of the three case studies used the resulting framework in combination with a participatory process that supported the adaptation planning, using the SWAP-Scenario Workshop and Adaptation Pathways method [11,74]. In each of these three cases studies, the framework was applied with the participation of a total of 70 participants in the six planning workshops. This participant evaluation provided feedback to support the discussion on the potential use and limitations of this study output. 


\subsection{Indicators of Efficacy of Adaptation Measures}

To assess the effectiveness of adaptation measures we measured the maintenance of the productivity in the different climatic conditions. Each strategy has a different function that can be considered a specific objective, which was transformed into an indicator. The quantification of the effectiveness of the adaptation measures was then performed by a literature review, using in google scholar keywords focused on the adaptation measure and the specific indicator, for example, "mulch" + "soil moisture". The peer-review literature validated the efficacy of the adaptation measures, but only in some studies, it is quantified. This quantification is then transformed into a percentage, regarding the amount of success that the specific indicator achieves. For example, if 5 centimetres of straw mulch reduce soil annual evaporation by $38 \%$, then this measure has the efficacy of $38 \%$. The same measure involving another technique, using $5 \mathrm{~cm}$ of gravel as mulch has, on the other hand, an efficacy of $81 \%$ in maintaining soil moisture. After a thorough literature review on the list of adaptation measures and indicators, a table with the efficacy of adaptation measures was produced. This table was used in the SWAP stakeholder workshops of adaptation planning of the case studies, to support decision-making, thus receiving feedback from end-users.

\subsection{Stakeholder Evaluation of Results}

The developed adaptation framework and indicators were subject to use and evaluation in the participatory planning of adaptation of agriculture and forestry in three case studies. There was a total of 70 participant stakeholders and 55 responses in evaluation questionnaires, 14 for Herdade da Ribeira Abaixo farm, 18 for Coitadinha farm and 23 for Mértola municipality. After the workshop, the participants were asked how they evaluated the quality of the workshop of planning, its content, method and results, in a score of 1 (no opinion), 2 (bad), 3 (not sufficient), 4 (reasonable), 5 (good) and 6 (very good). The average of the evaluation of all the responses to all the case studies was 5.4. Regarding the two Vision and Planning workshops that were organised in each of the three case studies and used the framework presented in this study, $98 \%$ of stakeholders considered the presentations good or very good, $96 \%$ of stakeholders considered the content good or very good, $89 \%$ considered the final outcomes as good or very good and $95 \%$ considered the overall quality as good or very good. Furthermore, $100 \%$ of stakeholders considered workshop facilitation to be good or very good and $96 \%$ considered workshop materials to be good or very good. As a general evaluation of the whole process, participants were asked to evaluate in a score of 1 (no opinion), 2 (not satisfying), 3 (reasonably satisfying), 4 (quite satisfying) and 5 (totally satisfying). The 55 responses showed that $100 \%$ of stakeholders considered that the Method was totally or quite satisfying, and $100 \%$ of the stakeholders considered that regarding their Expectation the process was totally or quite satisfying.

\section{Results and Discussion}

\subsection{Framework for Adaptation in Agroforestry}

Based on the Vulnerability and DPSIR Frameworks, the literature review, several interviews and stakeholder workshops, we propose that vulnerability to climate change in agriculture and forests of the Mediterranean is a function (f) of several variables and can be understood and managed effectively using the following proposed framework (see Figure 3):

Climate Vulnerability $=\mathrm{f}$ (Potential impacts), $\mathrm{f}$ (Adaptive capacity).

Potential impacts $=\mathrm{f}$ (Exposure) [f (Climate Change Mitigation), $\mathrm{f}$ (Microclimates)], $\mathrm{f}$ (Ecosystem Resilience and Sensitivity), $\mathrm{f}$ (Protection).

This adaptation framework for agriculture and forestry combines the vulnerability framework, the DPSIR framework and a thorough organization of adaptation measures into strategies, based on the cause effect relation and the objectives of vulnerability reduction. 


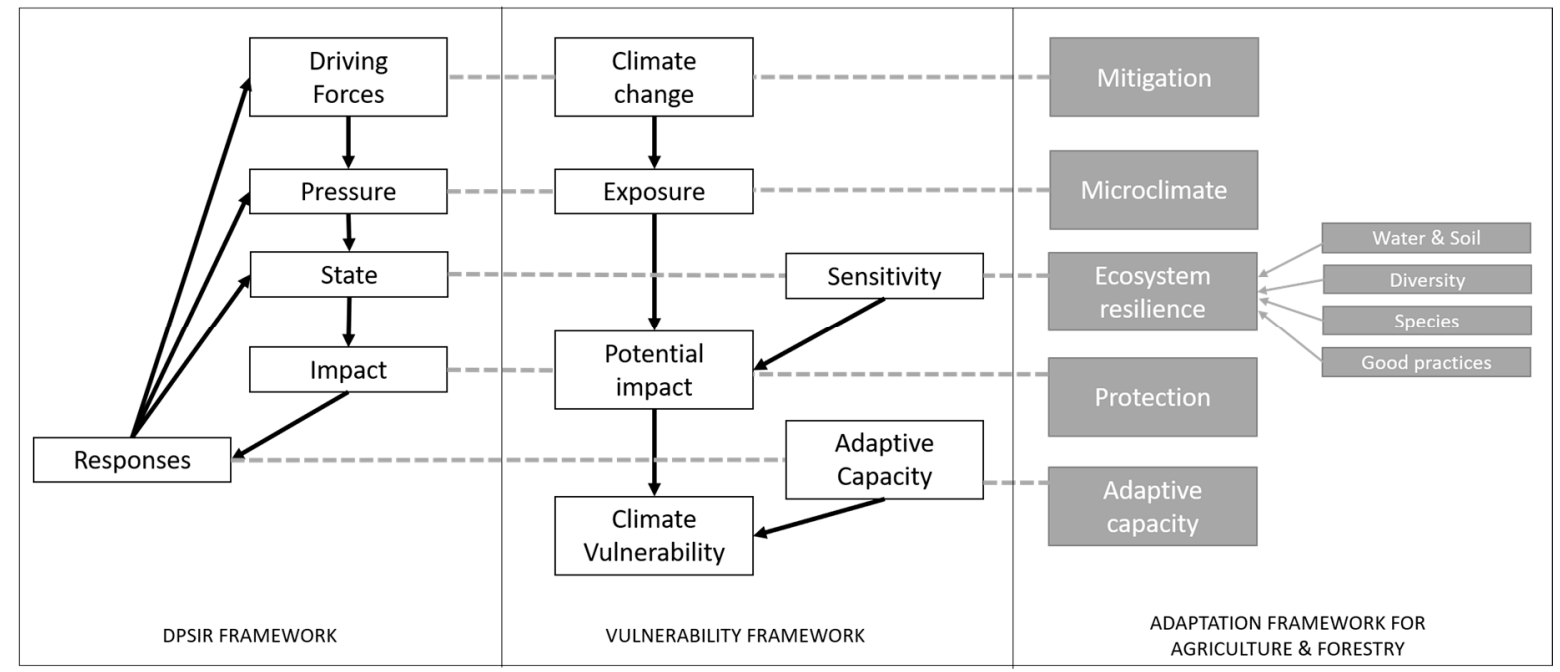

Figure 3. Adaptation Framework for Agriculture \& Forestry. The scheme presents the interlinkages between the vulnerability framework, the DPSIR and the proposed adaptation framework. The boxes define the approach of the DPSIR framework (left), the Vulnerability Framework (centre) and the adaptation strategies in the proposed framework Adaptation Framework for Agriculture and Forestry (right).

Since a strategy describes how the goals will be achieved by the means, its design implies the definition of specific adaptation objectives, and depends on the understanding of the functioning of the agroecosystem and the causes for the climate vulnerability. We can divide the factors that limit or condition the productivity of plants and trees into two classes: Abiotic and Biotic. Inside the Abiotic class, we can find anthropogenic or other causes for different factors: climate, pollution, topography, water, soil and fire. Inside the Biotic class, we can also find anthropogenic and other causes or influences for some of these factors: pests, diseases, ecosystem configuration and relations, species traits, and human management of plants with techniques such as pruning, grafting, trimming, irrigation, soil management, etc.

In the context of climate action aimed to adapt the system by reducing climate induced vulnerability, based on the present framework for agriculture and forestry, we start by looking at mitigation (reducing greenhouse gases and increasing its sinks) since it addresses the cause of the problem and it is an essential strategy to reduce climate vulnerability. According to the definition in the glossary of the Fourth Assessment Report of IPCC, adaptation is the adjustment in natural or human systems response to actual or expected climate [75] and thus mitigation is exterior to the concept of adaptation. On the other hand, since the main objective of climate adaptation planning is to reduce climate vulnerability, a framework that is developed to support decision making should be clear when presenting the cause effect relations of vulnerability, thus including mitigation action in its frame. Complementarily, maladaptation actions can result in higher greenhouse emissions, thus increasing the impact of climate change in others [20] and the assessment of the risk of maladaptation by Magnan et al. conclude that the risk of maladaptation should be put "at the top of the planning agenda", namely by the frameworks that support decision making [21]. Several studies have clarified the synergies between mitigation and adaptation, namely in the agriculture and forestry sector, reinforcing the importance and opportunities in analysing efforts of mitigation and adaptation with combined approaches [76-82].

Using this framework, after analysing mitigation to reduce vulnerability, we continued by looking at how to reduce exposure to the climate pressures, then how to increase the resilience of the agroecosystem and finally, which measures are effective to protect against the direct or indirect potential impacts of the climate pressures. Complementary to these, is the strategy of investing in the Adaptation Capacity, which has to be considered as a strategy in itself due to its importance, effectiveness and direct relation to the socioeconomic dimension of climate vulnerability [83]. 
The framework is explained bellow by presenting the adaptation strategies and a set of examples of adaptation measures for each adaptation strategy, based on the list of 162 measures (see Table A1):

1. Mitigation-The strategy for acting on the Driving Forces of the climate-induced vulnerability, consists of Mitigation. This means focusing on actions that reduce green-house gas emissions and increase carbon sinks. If mitigation is implemented effectively at the global scale, most of the climate impacts will be minimized [84]. Even though this is outside of the typical scope of adaptation, based on the vulnerability and DPSIR framework, it must be identified as the first response that acts on the cause of the pressure. In the agriculture and forestry sector, mitigation includes measures such as preventing fires [85], increasing soil organic matter [86], afforestation [87], and the reduction in greenhouse gases production in the farm [88]. According to Smith and Olesen, measures that have positive impacts on both mitigation and adaptation include: "(1) measures that reduce soil erosion, (2) measures that reduce leaching of nitrogen and phosphorus, (3) measures for conserving soil moisture, (4) increasing the diversity of crop rotations by choices of species or varieties, (5) modification of microclimate to reduce temperature extremes and provide shelter, (6) land use change involving abandonment or extensification of existing agricultural land, or avoidance of the cultivation of new land" [82].

2. Microclimates-According to the DPSIR framework, reducing the Pressure is the second priority when prioritizing responses. The Pressure is the Exposure to climate variables, as defined by the vulnerability framework. The Strategy of Microclimates consists of creating or using microclimates at the farm level in order to reduce the exposure to heat, cold, wind, water scarcity, etc. [89]. This strategy includes measures such as locating species on shaded North slopes (in the north hemisphere) [90], creating windbreaks [91], planting on the shade of trees or bushes [92-94], planting in riparian zones or around lakes or water reservoirs and locating species in areas with specific microclimates such as shade, sun, wind protection or wind breeze, no frost areas [95].

3. Ecosystem Resilience-The third strategy for adaptation, combining the use of the Vulnerability and DPSIR frameworks, consists of ecosystem resilience. Resilience is defined by "the capacity of systems to absorb disturbances and still retain the same structure and function while maintaining options to develop" [96]. The resilience of the farm ecosystem depends, according to the DPSIR framework, on the State of the ecosystem, and according to the vulnerability framework, on the Sensitivity of the agroecosystem. Reducing the sensitivity and improving the state of the ecosystem will, in principle, increase the resilience of the agroecosystem. Since the framework aims to address an ecological system (agriculture) and this strategy addresses the ecological sensitivity and resilience, we have detailed it in four sub-strategies through which farm ecosystem resilience can be promoted:

a. Water and Soils-The net primary production (NPP) of trees or rainfed agriculture in the Mediterranean climate is mostly limited by soil water availability [97]. Increasing water availability, namely in the soil, is an important strategy that has been extensively used in the past [98] and can reduce the sensitivity of the system to droughts, reduction in precipitation and water scarcity. Measures to increase water retention in soil such as finding an optimal tree density [99], lakes, swales [100,101], terraces [102], half-moons [103], mulch [104], increase organic matter in soil [103,105] or waterboxes [106] are included in this strategy.

b. Diversity-Approaches based on diversity, such as agroforests, silvopastoral systems, mixed tree crop systems, multi-strata forest gardens or vegetable gardens are widespread and have been used for centuries by farmers to minimize risk and ensure some productivity in unfavourable years $[79,107,108]$. Diversity in the ecosystem can significantly regulate plagues, pests, fires and negative impacts on biodiversity [109]. In addition, a diversity of families, species, varieties 
and genetic diversity will increase the capacity of the system to survive and prosper in different climate conditions [110-112] thus increasing its resilience [113]. Diversity can include measures such as micorrization [114] to increase survival rates; composted manure $[115,116]$ and the plant Phlomis purpurea to control pests [117]; diversification of fodder using edible shrubs adapted to drought [118] or increasing species richness to increase productivity [119].

c. Species-The farmer or decision maker can choose the species and crops according to the present and expected future climate. A farm ecosystem with species that are adapted to the future climate variables is more resilient to climate change $[19,120]$.

d. Good Practices-Promote silvicultural and pastoral practices that increase productivity while respecting the environmental carrying capacity in the long term, thus maintaining productivity in a sustainable routine. This strategy includes measures such as adequate pruning of trees, integrated rotational grazing, efficient irrigation, erosion control measures, pruning, tree protectors, fire prevention, etc. [121-125].

4. Protection-The end of the line, but often an urgent and needed strategy, is the protection of the system elements when a certain climate change occurs. When prevention is not implemented or is not enough, this strategy can be applicable to heat waves, droughts, water scarcity, storms, or plagues in order to combat the effects of climate change impacts. This strategy includes adaptation measures such as the increase of food storage (for example hay for drought years), farm insurance, using pesticides for plague control, fire combat or irrigation [126].

5. Adaptive Capacity-Finally, a strategy transversal to the whole adaptation process consists of increasing the adaptive capacity of the farmers and the region, therefore increasing the available set of capitals that can be used for adaptation and the capacity to mobilize them for this objective $[96,127]$. The capitals for adaptation include human, social, political, financial, natural, and cultural capital [127], and resources such as technology and infrastructure, information, knowledge, institutions and the capacity to learn [128]. Without adaptive capacity, all the previously mentioned strategies cannot be properly considered, assessed, evaluated, and implemented. Increasing Adaptive Capacity includes strategies such as: (a) increasing knowledge; (b) increasing financial capacity; (c) monitoring; (d) reflexive governance that can reflect and integrate the challenges of a changing system [129] and also foster the markets that can make viable the climate adapted farming [19].

The main strength that we find in this framework is, to begin with, its capacity of framing the adaptation measures and strategies regarding the main adaptation objective which is to reduce climate vulnerability. If decision-makers want to reduce the climate vulnerability of their farm or territory, they can find support and structure in this framework to understand what the strategies are and what measures they can use, either to reduce the exposure to climate change, to make their system more resilient and finally to protect against potential impacts.

This framework integrates the complexity behind the large number and type of adaptation measures, listed in the literature and proposed by several previous adaptation frameworks for agriculture and forestry, organizing them into a hierarchy of Strategies and Measures, as seen in Table 2 and in Appendix A. This hierarchization is of particular importance to the main objective of this framework is which is to support decision making by clarifying the hierarchy of adaptation measures towards the reduction in climate vulnerability. Other categories used in adaptation frameworks such as (i) types of adaptation, (ii) temporal scale of adaptation, and (iii) aim, timing, duration, scale, responsibility and form, are therefore considered complementary to this end. For further integration of these categories, other tools, such as a multicriteria table, can be used to present to stakeholders and give more information regarding the adaptation strategies and measures. Concerning the integration of adaptation domains, it is relevant to acknowledge that the strategy of 
Protection includes several measures of Disaster Risk Reduction (DRR), thus supporting the integration of these two domains: DRR and Adaptation.

Table 2. Adaptation framework organized by strategies and a short list of adaptation measures that result from interviews, literature review, analysis and organization on cause effect relation with climate vulnerability.

\begin{tabular}{cc}
\hline Strategy & Strategy Short Description \\
\hline 1. Mitigation & $\begin{array}{c}\text { Contribute to reducing greenhouse gases } \\
\text { by carbon sequestration, reduction in } \\
\text { energy consumption and production of } \\
\text { renewable energy }\end{array}$ \\
2. Microclimate & $\begin{array}{c}\text { Reduce exposure to climate pressure by } \\
\text { using or creating microclimates in which } \\
\text { there is more or less sun, wind, heat, cold } \\
\text { or water. }\end{array}$ \\
(a) Water and Soils & $\begin{array}{c}\text { Optimize the relation of water demand } \\
\text { and water availability by } \\
\text { increasing/regulating the amount of } \\
\text { water in the soil; increasing the water } \\
\text { availability on the landscape by water } \\
\text { harvesting }\end{array}$ \\
&
\end{tabular}

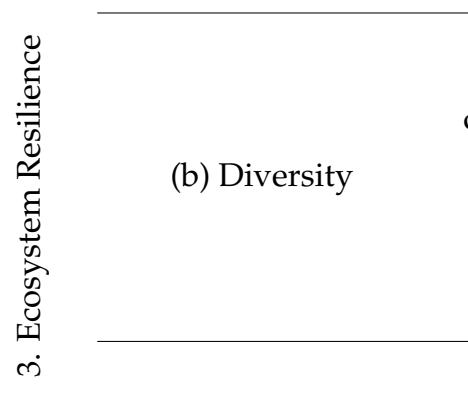

(c) Species

Use species that are comfortable within the climate variations expected to the future, so that resistance increases.

Using a diversity of species, varieties, crops, genes, practices, timings to create redundancy, diminish risk, create self-regulation of the ecosystem, and increase the autonomous adaptive capacity of species and landscape.

\section{Adaptation Measures (Short List)}

- Prevent fires;

- Afforestation;

- Increase soil organic matter;

- Increase permanent pastures;

- $\quad$ Reduce machine hours;

- Reduce external input consumption (fertilizers, animal feed, etc.);

- Produce renewable energy on the farm:

- Plant trees in shade areas such as north slopes (in north hemisphere);

- Plant trees near riparian zones;

- Install windbreaks to reduce evaporation;

- Increase tree canopy cover to reduce heat and evaporation;

- Mulch;

- Swales;

- Half-moons;

- Terraces;

- Increase soil organic matter;

- Biochar;

- Lakes and dams;

- Use diverse species and diverse genetic material to promote natural autonomous adaptation of species;

- Use different varieties of the same species;

- Install drought resistant fodder banks;

- $\quad$ Pest control through the application of composted manure;

- Mycorrhizal inoculation;

- Choose and use species that are adapted to climate conditions namely in regard to temperature and rainfall thresholds;

- Use varieties that are adapted to climate conditions;

- Increase the success of afforestation;

- Tree maintenance through pruning and

(d) Good Practices

Increase the resistance of the system by improving the state of the system
Diminish physical or socio-economic impacts by compensating the impacts with the end of the line measures

\section{Adaptive Capacity}

Increase the available set of capitals that can be used for adaptation and the capacity to mobilize them for this objective trimming;

- Rotational grazing;

- Conservation tillage;

- Protect roots of trees from ploughing;

- $\quad$ Fire prevention and combat;

- Deficit irrigation;

- $\quad$ Protection of infrastructures;

- Insurance;

- Increase storage of fodder;

- Rural extension;

- Increase and disseminate knowledge and good practices;

- Reduce legal and bureaucratic obstacles;

- Create a market for adapted crops/varieties:

- Articulate policies, programs and financial system to promote adaptation; 
One of the challenges that we observed when attempting to organize adaptation strategies and measures is to develop an adaptation framework that is conceptually robust and at the same time functional for stakeholders in the adaptation planning process. The organization of measures inside the presented strategies and their relation to vulnerability reduction has been well evaluated and easily accepted by stakeholders, farmers, and experts in the adaptation planning workshops in which it was used. During the participatory planning workshops, not only there positive feedback about the clarity of the adaptation strategies and measures, but also stakeholders were able to create an adaptation plan together for the territories at stake in all three case studies with the support of two workshops, thus suggesting that this organization and hierarchy between strategies and measures are satisfactory for the understanding and planning of the adaptation in the sector. The positive evaluation of stakeholders of the adaptation process supports the functional character of the framework, and further discussion can contribute to the understanding of its conceptual base, its adequate use, its limitations, and the research needed to develop future improvements.

One important attribute of this organization of measures inside strategies is that a given measure can easily fit in more than one strategy. For example, applying composted manure to soil serves, on one hand, as a Water and Soil strategy, since it increases, by $25 \%$, the capacity of water retention of the soil [103], and, on the other hand, composted manure is a strategy of Diversity, since the diversity of microorganisms in the compost serve as a pest control, namely with an efficiency of $39-76 \%$ in controlling P. cinnamon, an oomycete that kills cork and holm oaks [115]. This strengthens the understanding of the different functions of adaptation measures, by clarifying the multiple positive effects of an adaptation measure by placing it in different strategies, therefore supporting different objectives. This also creates the possibility of using different indicators of efficacy for an adaptation measure for the different objective that it is trying to be achieved, as mentioned in the example above.

\subsection{Efficacy for Adaptation in Agriculture and Forestry}

In order to answer the question of "how effective is an adaptation measure", one needs to clearly identify what is the specific vulnerability reduction objective that measure is attempting to reach. The proposed adaptation framework shows that different objectives can co-exist for the success of the adaptation of a farm or territory.

Within the microclimate strategy it is possible to reduce exposure to climate variables such as solar radiation or wind and decrease temperature, decrease evaporation and increase soil moisture. It is also possible to reduce the exposure to storms and heat waves, water scarcity and frost. Within the strategy of water and soils it is possible to increase the soil moisture and therefore reduce the potential water scarcity that would result from the decrease in precipitation or increase in droughts. With the strategy of diversity, it is possible to intervene on indirect effects of climate pressure such as the productivity of the whole agroecosystem or the capacity of the species and ecosystem to respond and autonomously adapt to the potential impacts of loss of productivity that come from pest, diseases, increased evapotranspiration, heat, water scarcity and consequent limitations to growth.

Following this analysis, the specific objectives and indicators can be:

(i) Reduction in precipitation causes water scarcity. The objective is to prevent water scarcity and prevent a decrease in soil moisture. The indicator can be Soil Moisture.

(ii) An increase in temperature causes the death or reduction in productivity of certain species, when temperature rises above a given threshold. Therefore, the objective and the indicator can be Temperature regulation.

(iii) An increase in temperature and decrease in precipitation cause increased mortality and unsuccess rate in reforestation. Therefore, the objective can be the increase in the success rate of reforestation and the indicator can be the Plantation success rate. 
(iv) A change in climate variables and patterns can originate more or different pests and diseases. The objective and indicator can therefore be Pest Control.

(v) An increase in the frequency, duration and intensity of Droughts can decrease the amount of fodder production for grazing animals. The objective and indicator can therefore be Fodder production during drought.

(vi) A decrease in precipitation can cause a decrease in productivity. The objective can therefore be "maintain crop productivity" and the indicator, Crop productivity.

Further objectives can be identified to reduce the vulnerability and adapt a territory or farm to climate change. If further objectives are identified, likely new indicators can and must be designed in order to confront with literature review and quantify the efficacy of the adaptation measures. The objectives and indicators mentioned above and presented in Table 3 were identified to support the adaptation planning of the three case studies and its applicability is limited by the amount of literature with quantitative studies that can provide relevant information about these adaptation measures.

Table 3. Efficacy of Adaptation Measures. Columns include the Strategy and the Measure of adaptation, the Indicator of Success, a description of its efficacy, a value in percentage, according to each descriptor, and, in participatory workshops, a qualitative confidence value, attributed by the planners, according to the quality of the reference and the adequacy of the reference for the context under study and planning.

\begin{tabular}{|c|c|c|c|c|c|}
\hline Strategy & Indicator & Adaptation Measures Used & Efficacy (\%) & Efficacy Descriptor & References \\
\hline \multirow{4}{*}{ 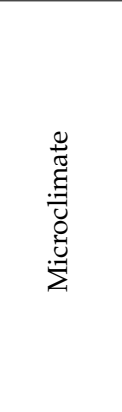 } & Soil moisture content & $\begin{array}{c}\text { Placement within microclimates } \\
\text { (e.g., shaded areas; riparian } \\
\text { zones) }\end{array}$ & $40-67 \%$ & Higher regeneration success & [90] \\
\hline & Temperature regulation & $\begin{array}{l}\text { Planting trees in the shade (e.g., } \\
\text { under bushes) }\end{array}$ & $50 \%$ & Higher regeneration success & [94] \\
\hline & Soil moisture content & Windbreak with vegetation & $35 \%$ & $\begin{array}{l}\text { Lower evaporation within a } \\
\text { distance from the windbreak of } \\
4 \times \text { its height }\end{array}$ & [91] \\
\hline & Temperature regulation & $\begin{array}{c}\text { Increase Montado's density (to } \\
\text { increase shade) }\end{array}$ & $40 \%$ & $\begin{array}{c}\text { Shade generates } 40 \% \text { less heat. } \\
\text { The decrease in } 2-5{ }^{\circ} \mathrm{C} \text {. The } \\
\text { increase in natural regeneration } \\
\text { up to } 2 \times\end{array}$ & {$[92,93]$} \\
\hline \multirow{6}{*}{ 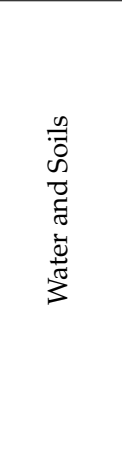 } & Soil moisture content & $\begin{array}{l}\text { Mulch (ex. straw, leaf litter, } \\
\text { stones, sawdust) }\end{array}$ & $38-81 \%$ & $38-81 \%$ water, $67 \%$ productivity & [104] \\
\hline & Soil moisture content & $\begin{array}{l}\text { Half-moon with stone walls } \\
\text { (shape the landform to store } \\
\text { more water) }\end{array}$ & $59-84 \%$ & $\begin{array}{c}\text { Water retention, organic matter, } \\
\text { nutrients \& production } \\
\text { (increase) }\end{array}$ & [103] \\
\hline & Soil moisture content & $\begin{array}{l}\text { Terraces (shape the landform to } \\
\text { store more water) }\end{array}$ & $16 \%$ & $\begin{array}{l}20 \% \text { increase in productivity in } \\
\text { wheat, } 16 \% \text { water increase }\end{array}$ & {$[102]$} \\
\hline & Soil moisture content & $\begin{array}{l}\text { Swale (shape the landform to } \\
\text { store more water) }\end{array}$ & $2-100 \%$ & The increase in water in the soil & {$[100,130]$} \\
\hline & Soil moisture content & Biochar in the soil & $4 \%$ & $\begin{array}{l}\text { Soil water retention capacity } \\
\text { (increase) }\end{array}$ & [105] \\
\hline & Soil moisture content & Waterboxx or similar & $12.4 \%-30.2 \%$ & Increased soil moisture & [106] \\
\hline \multirow{6}{*}{ 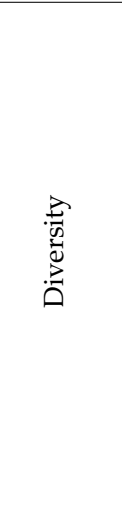 } & Plantation success rate & Mycorrhizal inoculation & $21-29 \%$ & $\begin{array}{l}\text { Increase in regeneration success } \\
\text { rate (year } 1 \text { and } 2 \text { ) }\end{array}$ & [114] \\
\hline & Pest control & $\begin{array}{l}\text { Pest control through the } \\
\text { application of composted } \\
\text { manure }\end{array}$ & $39-76 \%$ & $\begin{array}{l}\text { Per cent inhibition of colony } \\
\text { diameter of P. cinnammomi }\end{array}$ & [115] \\
\hline & Pest control & $\begin{array}{c}\text { Pest control through application } \\
\text { in the soil of Phlomis purpúrea } \\
\text { extract }\end{array}$ & $85 \%$ & Phytphthora cinnammomi control & {$[117]$} \\
\hline & $\begin{array}{l}\text { Fodder production during } \\
\text { drought }\end{array}$ & Drought resistant fodder banks & $30 \%-50 \%$ & Shrub fodder biomass (increase) & [118] \\
\hline & $\begin{array}{c}\text { Fodder production during } \\
\text { drought }\end{array}$ & $\begin{array}{l}\text { Living fence with drought } \\
\text { resistant native species }\end{array}$ & $30 \%-50 \%$ & Shrub fodder biomass (increase) & [118] \\
\hline & $\begin{array}{c}\text { Fodder production during } \\
\text { drought }\end{array}$ & Biodiverse permanent pastures & $0 \%$ & $\begin{array}{c}\text { Productivity increases in } \\
\text { drought year }\end{array}$ & [131] \\
\hline
\end{tabular}


Table 3. Cont.

\begin{tabular}{|c|c|c|c|c|c|}
\hline Strategy & Indicator & Adaptation Measures Used & Efficacy (\%) & Efficacy Descriptor & References \\
\hline $\begin{array}{l}\stackrel{\mathscr{U}}{\tilde{U}} \\
\text { की } \\
\text { की }\end{array}$ & Crop productivity & $\begin{array}{l}\text { Change to species adapted to } \\
\text { climate conditions }\end{array}$ & $100 \%$ & & \\
\hline \multirow{2}{*}{ 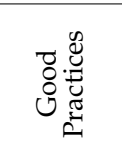 } & Plantation success rate & $\begin{array}{l}\text { Natural regeneration using } \\
\text { individual protectors }\end{array}$ & $32-77 \%$ & $\begin{array}{l}\text { Regeneration success rate (open } \\
\text { vs shade covered) }\end{array}$ & [124] \\
\hline & Crop productivity & $\begin{array}{l}\text { Tree maintenance through } \\
\text { pruning and paring }\end{array}$ & $0 \%$ & Increase in acorn production & {$[125]$} \\
\hline 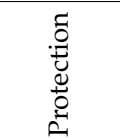 & Crop productivity & Occasional irrigation/deficit & $89 \%$ & $\begin{array}{l}\text { Almond productivity } \\
\text { maintenance in case of drought }\end{array}$ & {$[126]$} \\
\hline
\end{tabular}

The table of Efficacy of Adaptation Measures includes as columns the Strategy and the Measure of adaptation, the Indicator of Success, a description of its efficacy, and a value in percentage, according to each descriptor. The table of the efficacy of adaptation measures can be considered an application of the proposed adaptation framework. While the results in this table of efficacy include a choice of examples and literature review that fits the Mediterranean climate, other studies can be found that are more adequate to other climate regions. While the list of adaptation measures that have been identified in the literature and interviews can surpass 162 measures (see Table A1), on the table of efficacy, the number of measures is only close to 20, which reinforces the need for further literature review and research on the efficacy of adaptation measures based on these indicators and objectives.

Regarding the indicators and table of efficacy, one of its main assets is the possibility to compare the efficacy of the adaptation measures. The information on the efficacy has been considered by the stakeholders as very relevant and supportive for their decision-making. Moreover, for researchers and the project team this information has been considered very supportive to create and design the adaptation pathways for this sector, and in these specific areas.

Furthermore, when a measure is not supported by a study that assesses and quantifies its efficacy, it does not enter the table of efficacy, thus supporting the identification of knowledge gaps and the need for further literature review or need of specific research studies. The resulting table presents adaptation measures in all farm-level strategies but some of its studies of effectiveness cannot be generalized for all contexts and conditions. For example, the efficacy of mulch for water retention can be different depending on the soil structure and on the frequency of rain (and days without rain) in each region. Informing stakeholders with a general efficacy level for an adaptation measure, based on a study that only addressed specific conditions may be misleading to the extent that can misinform stakeholders into adopting an ineffective adaptation measure for their context. This raises the need for very clear communication on the limitations of each study and efficacy number. Additionally, it invites the technical team that is supporting a specific adaptation process, to review the literature, based on the same indicators, while focusing on those studies that are most relevant to the context under planning.

\subsection{Application of the Framework in Case Studies}

The number of adaptation measures in the Adaptation Framework proposed is not equal in the different strategies (see Figures 4 and 5), since it is a result of the measures identified in the literature and proposed by farmers and other stakeholders. The list should be read as a permanent work in progress as new measures can be identified from the literature or practice. Some measures can also be disaggregated into several, as they name different species or specific techniques used in different contexts. Since this framework supports analysis and decision making on adaptation, we have mapped all the adaptation measures present in the Portuguese Adaptation Strategy and the adaptation plans of the 
three case studies, identifying how many measures are selected from each adaptation strategy (see Figures 4-6).

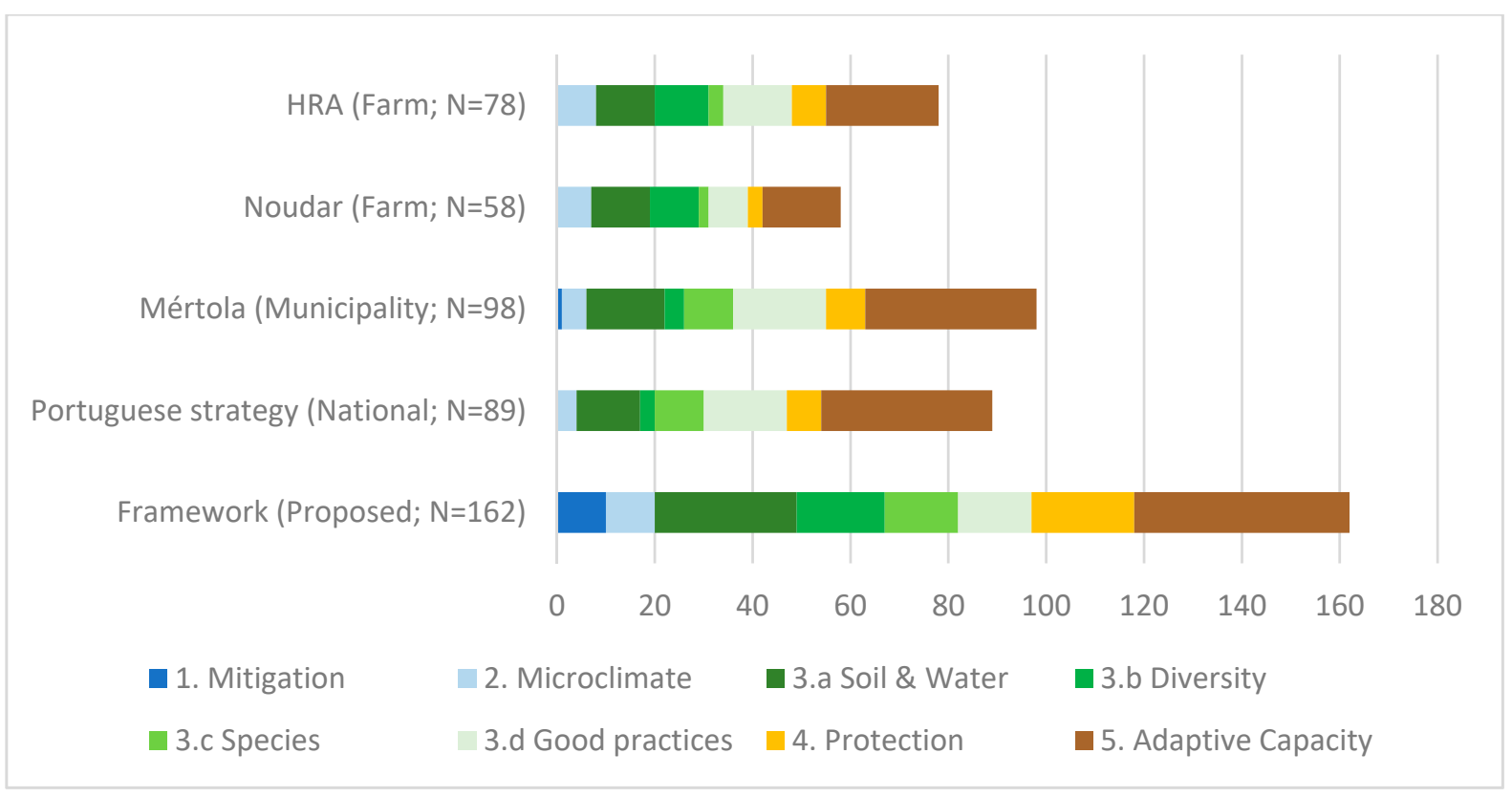

Figure 4. Number of adaptation measures per adaptation strategy (detailed level) identified in the adaptation plans of the three case studies, plus the Portuguese National Adaptation Strategy in comparison to the proposed Framework.

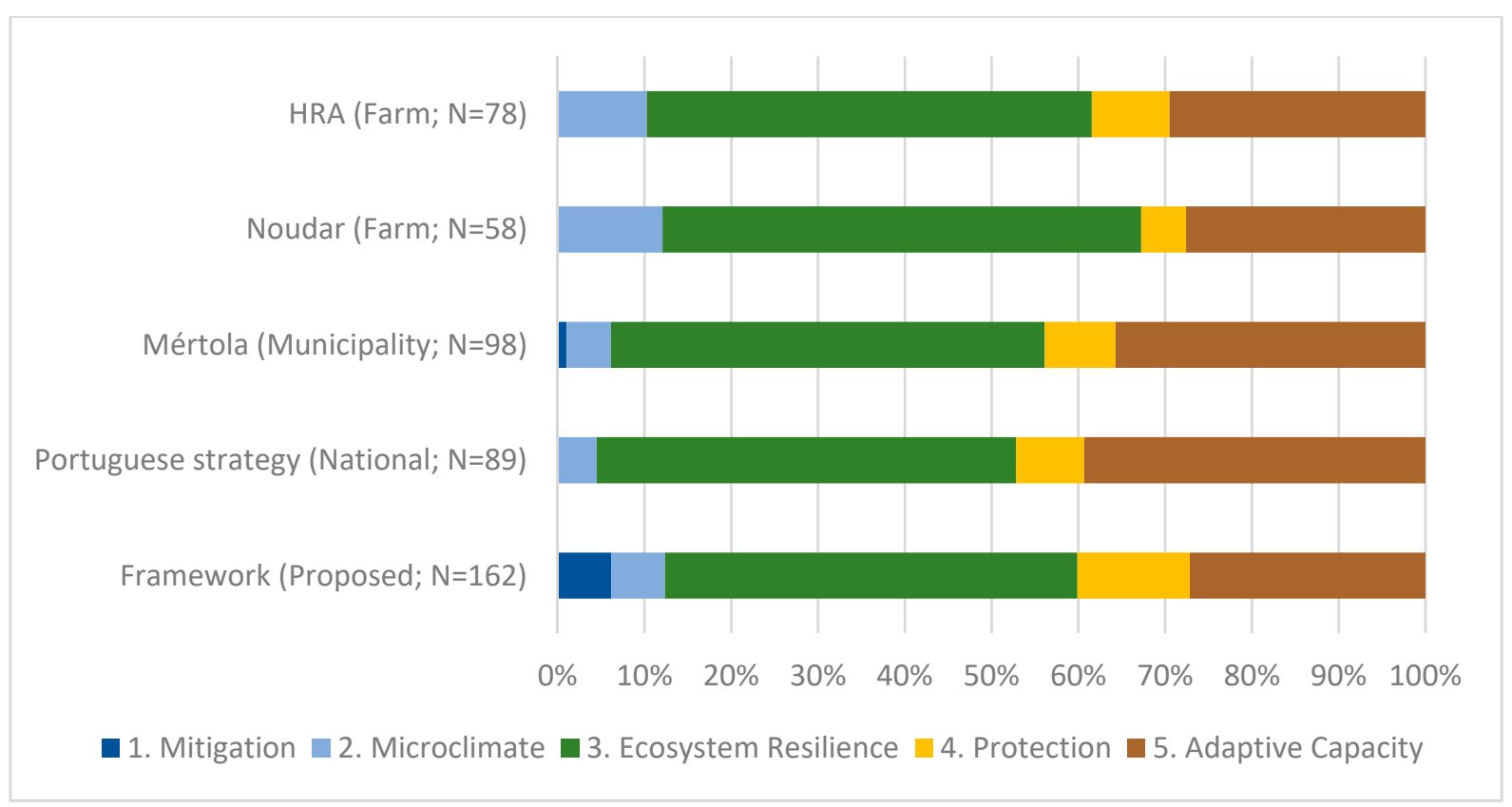

Figure 5. Percentage of adaptation measures per adaptation strategy identified in the three case studies adaptation plans, plus the Portuguese National Adaptation Strategy in comparison to the proposed Framework. 


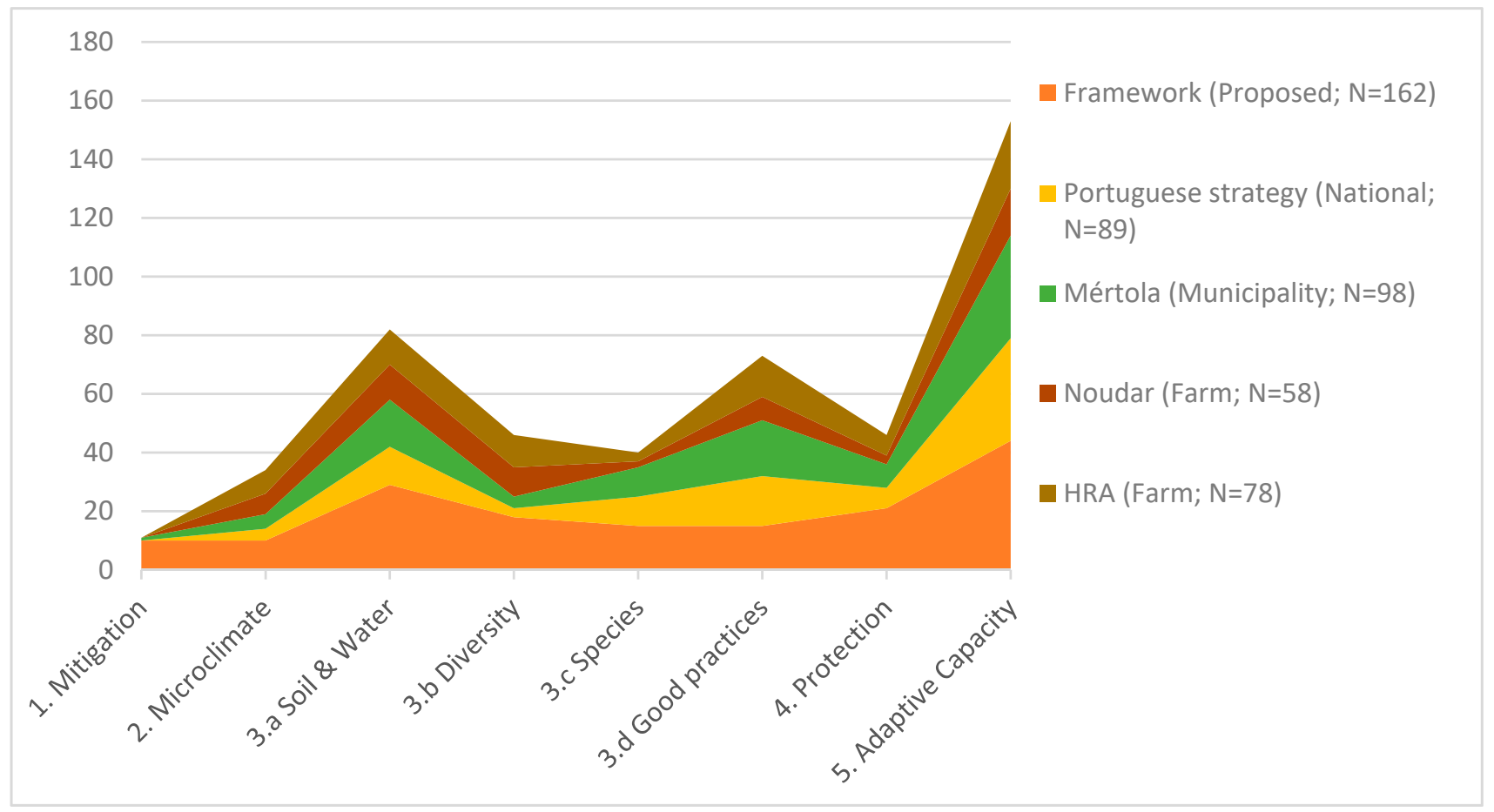

Figure 6. Number of adaptation measures (accumulated) identified in the case studies adaptation plans, in the Portuguese National Adaptation Strategy and in the proposed Framework, organized by detailed adaptation strategies.

The numbers of measures selected show that the Mitigation strategy was only used once and only had measures in the Mértola case study. In the Portuguese National Adaptation Strategy, this result is likely due to the fact that there are other policy instruments only dedicated to mitigation, namely the Portuguese low carbon roadmap 2050 [132]. In Mértola, the measure of installing solar panels in farms was reached by consensus in the long-term vision of the adaptation of agriculture and forestry, but, in the adaptation pathways, in the zonal plans and in the adaptive capacity measures, there is no further mention to this measure; thus, lacking more specific planning is lacking within the context of the adaptation plan for this sector. In the other case studies, mitigation measures were not selected.

Although mitigation measures are essential to reduce vulnerability, has shown by the framework, they are not selected in the adaptation plans, despite the use of this framework in the adaptation planning process. This shows the importance of having complementary instruments to plan and enforce mitigation, so that climate action and vulnerability reduction is not limited to adaptation measures. On the other hand, it is also important to notice that several of the adaptation measures selected in all case studies, namely in the strategy of microclimates, soil and water and good practices, are directly contributing to mitigation by storing carbon above and below ground, or indirectly by reducing inputs and thus GG emissions.

The analysis of Figure 5 shows that Ecosystem Resilience is the strategy with the highest percentage of measures selected, followed by Adaptive Capacity. In average 52.2\% of the adaptation measures selected by the three case studies are dedicated to Ecosystem Resilience, 30.9\% to Adaptive Capacity, 9.1\% to Microclimates, 7.4\% to Protection, and 0.3\% to Mitigation. In more detail Figure 6 shows that "Soil \& water" and "Good practices" are the strategies with more measures selected. This suggests the importance given to these strategies in the context of the case studies.

From the perspective of the DPSIR model, it is wise to act first on the causes and then on the consequences, which raises the question of why so few measures are used in the strategy Microclimates strategy, the one that can reduce exposure to the climate pressure. This can be due to the fact that few measures exist on this strategy, the efficacy of these measures 
is only studied for few measures or their efficacy is not yet totally perceived/integrated by stakeholders. On the other hand, in future studies it would be relevant to evaluate not only the number of measures used per strategy but the extent to which they have been used in the adaptation efforts, namely in terms of financial investment.

Investing in adaptive capacity is the second most used strategy in these case studies, which is a positive result for the use of this framework, since autonomous adaptation highly depends on adaptive capacity levels and investments in adaptive capacity are considered indispensable to the success of adaptation in agriculture [133].

\section{Conclusions}

Farmers, foresters, and other agroforestry agents need to make decisions every day on their future endeavours and presently they are pressured to include climate change in their planning. Even though scientific knowledge is never complete and able to provide all the necessary recommendations for all farm activities, it is important that agricultural and forestry activities are supported with the best available knowledge to plan for climate change. The adaptation framework presented here is designed to make comprehensible, organize and effectively communicate adaptation variables, strategies and measures for the agriculture and forestry sectors. If the planning process is supported by researchers or technicians that can perform literature review on the efficacy of adaptation measures based on the presented indicators, this framework and table of efficacy can be updated and tailored to each context, thus improving common knowledge. This framework has been effective for the planning of adaptation in three case studies which shows that it has the capacity of being used in practice for adaptation planning. Stakeholders that participated in the adaptation planning evaluated the content, process, and outcomes as good and very good. With this framework it also possible to assess and compare the adaptation strategies and measures used in the different case studies, drawing conclusions about priorities and the adaptation actions that are happening in the territory. Its use in different contexts is presently under experimentation so there is space for continued improvement, for example, in the literature review on the efficacy of adaptation measures, in the further integration of the details in adaptation measures and specific objectives, and in the usability in different contexts. Its capacity to highlight knowledge gaps on the efficacy of adaptation measures to different agriculture and forestry contexts is considered relevant and supportive for the definition of future research needs. Its use for the assessment of adaptation plans and actions in different regions is also a relevant potential use and an avenue for future research.

Author Contributions: The first author, A.V., is the principal author of this article. All authors contributed to the study conception and design, material preparation, data collection and analysis. The first draft of the manuscript was written by A.V. and all authors contributed as joint authors in the study and manuscript. All authors have read and agreed to the published version of the manuscript.

Funding: This research was funded by BASE Bottom up Adaptation for a Sustainable Europe (2012-2016) (Grant Agreement No. 308337), EEA Grants/Programa AdaPT project AdaptForChange (2015-2016) and the EU LIFE Programme with project LIFE Montado-Adapt (LIFE15 CCA/PT/000043) (2016-2021). This research was also funded by Fundação para a Ciência e Tecnologia who supported the PhD grant PD/BD/113929/2015 of André Vizinho, as well as the FCT Investigator contract (IF/00940/2015) of Gil Penha-Lopes. The APC was funded by the cE3c FCT Unit funding UIDB $/ 00329 / 2020$.

Institutional Review Board Statement: Not applicable.

Informed Consent Statement: Informed consent was obtained from all subjects involved in the study. 
Data Availability Statement: The data presented in this study is openly available in the reports of the adaptation plans or workshops included in this study. Should the reader require additional detail or information, it can be provided upon request to the authors. Link 1: https://www.researchgate.net/ publication/332144516_Plano_de_Adaptacao_de_Mertola_as_Alteracoes_Climaticas_-_Sector_da_Agricultura_e_Florestas (accessed on 8 December 2020); Link 2: https://www.researchgate.net/ publica-tion/333603290_Climate_Change_Adaptation_Plan_of_Herdade_da_Ribeira_Abaixo_farm (accessed on 8 December 2020); Link 3: https:/ /www.researchgate.net/publication/333566708_ Climate_Change_Adaptation_Plan_of_Herdade_da_Coitadinha_Noudar_Natural_Park (accessed on 8 December 2020); Link 4: https:/ / www.researchgate.net/publication/348541537_Relatorio_do_ Workshop_da_Avaliacao_Multicriterio_das_Medidas_de_Adaptacao_a_Alteracoes_Climaticas_da_ Agricultura_e_Florestas_do_Alentejo (accessed on 8 December 2020); Link 5: https: / www.researchgate.net/publication/336580295_Participatory_State_of_the_Art_on_Adaptation_to_Climate_Change_ in_Alentejo (accessed on 8 December 2020).

Conflicts of Interest: The authors declare no conflict of interest. The funders had no role in the design of the study; in the collection, analyses, or interpretation of data; in the writing of the manuscript, or in the decision to publish the results.

\section{Appendix A}

Table A1. Climate Adaptation Measures for the Agriculture and Forestry sector in the Mediterranean Climate. These measures are compiled from 151 different references listed below.

\begin{tabular}{|c|c|c|c|c|}
\hline \#. & & Strategy & Measures & References \\
\hline 1 & \multirow{10}{*}{ 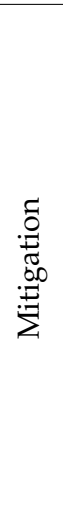 } & \multirow{4}{*}{ Carbon sink } & Charcoal in soil & {$[105,134-136]$} \\
\hline 2 & & & Increase in forest area & [137-140] \\
\hline 3 & & & Increase in soil organic matter & {$[86,141,142]$} \\
\hline 4 & & & Change from forage crops to permanent pastures & [143-145] \\
\hline 5 & & \multirow{6}{*}{$\begin{array}{l}\text { Reduction of GEE } \\
\text { emissions }\end{array}$} & Production of renewable energy on the farm & {$[84,146]$} \\
\hline 6 & & & Reduction of enteric fermentation through diet changes & {$[147,148]$} \\
\hline 7 & & & $\begin{array}{l}\text { Decrease energy consumption on the farm (reduce tillage, fuel, } \\
\text { fertilizer, etc.) }\end{array}$ & {$[149,150]$} \\
\hline 8 & & & Reduction of consumption in trading (transport, packaging) & {$[149,151,152]$} \\
\hline 9 & & & Composting of manure & {$[153,154]$} \\
\hline 10 & & & Decrease machine hours (p.e. with conservation tilling) & [155-157] \\
\hline 11 & \multirow{10}{*}{ 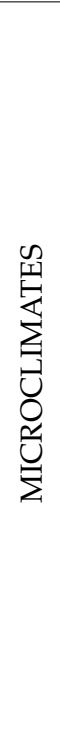 } & \multirow{4}{*}{$\begin{array}{l}\text { Locate in the most } \\
\text { appropriate } \\
\text { microclimates }\end{array}$} & $\begin{array}{l}\text { Plant in areas with specific microclimates such as shade, sun, } \\
\text { wind protection or wind breeze, regular presence of dew and } \\
\text { fog, no frost areas }\end{array}$ & {$[95,158-160]$} \\
\hline 12 & & & Plant in riparian zones, around lakes or water reservoirs & {$[95,159,160]$} \\
\hline 13 & & & $\begin{array}{l}\text { Plant or use natural regeneration in shaded slopes (North faced } \\
\text { slopes in North hemisphere) }\end{array}$ & [90] \\
\hline 14 & & & $\begin{array}{l}\text { Relocation of plants (e.g., vines) to higher latitudes (higher and } \\
\text { cooler areas) }\end{array}$ & [161] \\
\hline 15 & & \multirow{3}{*}{$\begin{array}{l}\text { Create microclimate to } \\
\text { increase shade }\end{array}$} & Plant trees or bushes to create shade for other plants or trees & [92-94] \\
\hline 16 & & & $\begin{array}{l}\text { Create shade (e.g., by not clearing shrubs completely (make } \\
\text { strips or stains) or plant bushes or trees for shade) }\end{array}$ & [92-94] \\
\hline 17 & & & Increase the density of the montado (to increase shade) & {$[93,160]$} \\
\hline 18 & & $\begin{array}{l}\text { Create microclimate to } \\
\text { lower temperature }\end{array}$ & $\begin{array}{c}\text { Lower air temperature with creation of water bodies (e.g., lakes); } \\
\text { creation of a phytoclimate with trees or plants; lower soil } \\
\text { temperature with mulch or shade. }\end{array}$ & {$[158,162,163]$} \\
\hline 19 & & \multirow{2}{*}{$\begin{array}{l}\text { Create microclimates to } \\
\text { increase water in the } \\
\text { soil }\end{array}$} & Creation of windbreak with vegetation & [164] \\
\hline 20 & & & $\begin{array}{l}\text { Afforestation (with trees with low water use) to increase air } \\
\text { moisture, rain, dew and reduce soil moisture loss. }\end{array}$ & [165-167] \\
\hline
\end{tabular}


Table A1. Cont.

\begin{tabular}{|c|c|c|c|c|}
\hline \#. & & Strategy & Measures & References \\
\hline 21 & \multirow{29}{*}{ 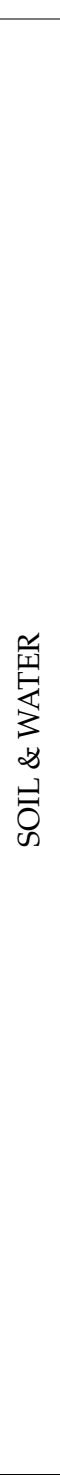 } & \multirow{7}{*}{$\begin{array}{l}\text { Preparation and modelling of terrain } \\
\text { to increase water retention }\end{array}$} & Half-moons/boilers in boomerang around the trees & [103] \\
\hline 22 & & & Half moons with stone walls & [103] \\
\hline 23 & & & Terraces (Model the terrain to store more water) & [102] \\
\hline 24 & & & Swales & {$[100,101]$} \\
\hline 25 & & & Plantation in contour & {$[168,169]$} \\
\hline 26 & & & Plantation and Mobilization in keyline & [170] \\
\hline 27 & & & Waterboxx or similar & [106] \\
\hline 28 & & \multirow{4}{*}{ Conservation tilling } & Tilling on the line & [171] \\
\hline 29 & & & Direct seeding & {$[172,173]$} \\
\hline 30 & & & Conservation tilling & {$[174,175]$} \\
\hline 31 & & & Non-tilling & [176] \\
\hline 32 & & \multirow{5}{*}{$\begin{array}{l}\text { Increase the water retention and } \\
\text { improve the soil with vegetation }\end{array}$} & vegetable cover with green manure & {$[177,178]$} \\
\hline 33 & & & Mulch & {$[104,179]$} \\
\hline 34 & & & $\begin{array}{l}\text { Chop and drop: chop the herbs after the last rains } \\
\text { to get more organic matter protecting the soil }\end{array}$ & {$[177,180]$} \\
\hline 35 & & & Barriers of bush or vegetation in contour & {$[168,181]$} \\
\hline 36 & & & Manure & {$[178,179]$} \\
\hline 37 & & \multirow{4}{*}{ Increase the water storage capacity } & Create temporary ponds & {$[98,182]$} \\
\hline 38 & & & Create permanent Ponds/Lakes & {$[98,182]$} \\
\hline 39 & & & Irrigation from large dams & {$[98,182]$} \\
\hline 40 & & & Feeding of groundwater and aquifers & {$[183,184]$} \\
\hline 41 & & \multirow{4}{*}{ Improve the watering efficiency } & Drip Irrigation & [185] \\
\hline 42 & & & Use water-efficient irrigation systems and practices & [185] \\
\hline 43 & & & Use weather forecast for agricultural activities & [186] \\
\hline 44 & & & $\begin{array}{l}\text { Monitoring the amount of water required for } \\
\text { watering with probes }\end{array}$ & {$[187]$} \\
\hline 45 & & \multirow{4}{*}{ Improve the soil with additives } & Fertilization of soil with living organic matter & {$[179]$} \\
\hline 46 & & & Charcoal / biochar in soil & [105] \\
\hline 47 & & & Control soil $\mathrm{pH}$ and nutrients with additives & [179] \\
\hline 48 & & & Placement of treated sludge in the soil & {$[188]$} \\
\hline 49 & & Diversify the sources of water & Reuse of wastewater for irrigation & [189] \\
\hline 50 & \multirow{13}{*}{ 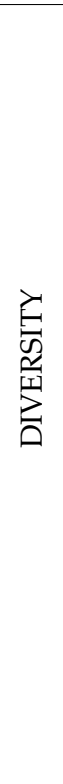 } & \multirow{2}{*}{ Use forage shrubs resistant to drought } & $\begin{array}{c}\text { Living fence with native species resistant to } \\
\text { drought }\end{array}$ & {$[190,191]$} \\
\hline 51 & & & Drought-resistant forage banks & {$[192,193]$} \\
\hline 52 & & \multirow{5}{*}{$\begin{array}{l}\text { Greater diversity of the type of culture, } \\
\text { species, varieties and genes }\end{array}$} & Preservation of wild fauna and flora & {$[194,195]$} \\
\hline 53 & & & Diversify cultures/crops & [196] \\
\hline 54 & & & Diversifying species and uses of soil & {$[119,197,198]$} \\
\hline 55 & & & Use of biodiverse permanent pastures & {$[131,199]$} \\
\hline 56 & & & $\begin{array}{l}\text { Diversification of varieties (drought resistance or to } \\
\text { take advantage of the anticipation of phenology) }\end{array}$ & {$[197,200]$} \\
\hline 57 & & \multirow{3}{*}{ Use biodiversity to control plagues } & $\begin{array}{l}\text { Organic farming practices for biological control of } \\
\text { pests }\end{array}$ & [201] \\
\hline 58 & & & $\begin{array}{l}\text { Increase the presence of insectivorous birds for pest } \\
\text { control }\end{array}$ & [201] \\
\hline 59 & & & Creation of biodiversity hotspots for insect balance & [109] \\
\hline 60 & & \multirow{3}{*}{$\begin{array}{l}\text { Increase the diversity and complexity } \\
\text { of the agro-ecosystems } \\
\text { Increase the diversity and complexity } \\
\text { of the agro-ecosystems }\end{array}$} & Inoculation with mycorrhizal fungi & {$[114,202]$} \\
\hline 61 & & & Conservation/regeneration of riparian zones & [109] \\
\hline 62 & & & $\begin{array}{l}\text { Increase the biological complexity of the forest } \\
\text { system }\end{array}$ & {$[109,203]$} \\
\hline
\end{tabular}


Table A1. Cont.

\begin{tabular}{|c|c|c|c|c|}
\hline \#. & & Strategy & Measures & References \\
\hline 63 & & \multirow{3}{*}{$\begin{array}{l}\text { Create or maintain } \\
\text { silvo-pastoral-systems }\end{array}$} & Create new complementary products from the Montado & {$[113,204]$} \\
\hline 64 & & & Value the complementary products of the Montado & [205] \\
\hline 65 & & & Maintain agro-silvo-pastoral system & [206] \\
\hline 66 & & \multirow{2}{*}{$\begin{array}{l}\text { Increase the diversity } \\
\text { with exotic species }\end{array}$} & Complementary products of Montado (exotic species) & {$[113,207]$} \\
\hline 67 & & & Agro-silvo-pastoral system with exotic species & [208] \\
\hline 68 & \multirow{15}{*}{ 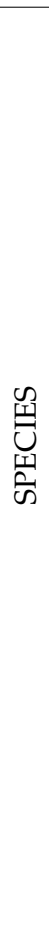 } & \multirow{6}{*}{$\begin{array}{l}\text { Selection of species } \\
\text { according to predicted } \\
\text { climate conditions }\end{array}$} & Switch to better adapted species & {$[209,210]$} \\
\hline 69 & & & $\begin{array}{l}\text { Choose better adapted varieties, with more adequate thermal } \\
\text { needs and more resistant to thermal and water stress }\end{array}$ & [211-213] \\
\hline 70 & & & Abandon cereal farming and adopt other crops such as forestry & [214] \\
\hline 71 & & & Use of more rustic and adapted animal species & [215] \\
\hline 72 & & & Use of short cycle species (annuals) to reduce watering & [216] \\
\hline 73 & & & $\begin{array}{c}\text { Extension of the production period by the use of earlier or later } \\
\text { cultivars }\end{array}$ & {$[216]$} \\
\hline 74 & & \multirow{5}{*}{$\begin{array}{l}\text { Increased genetic } \\
\text { diversity in crops }\end{array}$} & Greater and better genetic diversity in crops/species & {$[217,218]$} \\
\hline 75 & & & $\begin{array}{l}\begin{array}{l}\text { Use of locally adapted varieties (either by local seed or selected } \\
\text { clones) }\end{array}\end{array}$ & {$[217,218]$} \\
\hline 76 & & & Use local and indigenous cereal varieties & [219] \\
\hline 77 & & & Creation of local/regional seed banks & [219] \\
\hline 78 & & & $\begin{array}{l}\text { Preservation of intervarietal and intravarietal biodiversity in } \\
\text { olive trees }\end{array}$ & {$[64,220]$} \\
\hline 79 & & \multirow{4}{*}{$\begin{array}{l}\text { Selection and } \\
\text { improvement of species }\end{array}$} & Species selection and improvement & {$[64,217]$} \\
\hline 80 & & & $\begin{array}{c}\text { Genetic improvement program: selection of cultivars adapted to } \\
\text { thermal stress, drought, etc. }\end{array}$ & [64] \\
\hline 81 & & & $\begin{array}{l}\text { Collect and use seeds from the best plants from the most adverse } \\
\text { locations }\end{array}$ & {$[221,222]$} \\
\hline 82 & & & Installation of rootstocks more resistant to water shortage & [223] \\
\hline 83 & \multirow{15}{*}{ 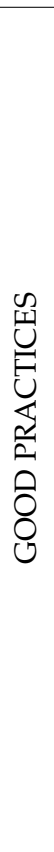 } & \multirow{7}{*}{ Forestry } & Increase soil organic matter & [141] \\
\hline 84 & & & Promote and maintain mycorrhizae in soil & [202] \\
\hline 85 & & & Crop rotation & [224] \\
\hline 86 & & & Fertilization with compost (e.g Bokashi method) & [225] \\
\hline 87 & & & Individual Protectors of natural regeneration & [124] \\
\hline 88 & & & Tree maintenance with pruning & [125] \\
\hline 89 & & & Cork Oak climax forest in sloping areas & [33] \\
\hline 90 & & \multirow{4}{*}{ Animals } & Soil tilling with pigs & [226] \\
\hline 91 & & & $\begin{array}{l}\text { Integrated management of grazing to promote forest } \\
\text { regeneration and clearing of weeds }\end{array}$ & [196] \\
\hline 92 & & & $\begin{array}{l}\text { Integrated and intensive rotation of livestock (Holistic } \\
\text { management) }\end{array}$ & {$[226,227]$} \\
\hline 93 & & & Feed livestock with sprouted cereal & [228] \\
\hline 94 & & Fruticulture/Vinyard & Use sturdy rootstocks & [223] \\
\hline 95 & & \multirow{3}{*}{ Annual crops } & $\begin{array}{l}\text { Adjust the date of sowing/planting according to the thermal } \\
\text { regime of each year to extend the production cycle }\end{array}$ & [18] \\
\hline 96 & & & Use of the best practices of rainfed agriculture & {$[122,229]$} \\
\hline 97 & & & $\begin{array}{l}\text { Make two irrigated crops in the same year (due to increased } \\
\text { heat) for cattle feeding }\end{array}$ & {$[18,230]$} \\
\hline
\end{tabular}


Table A1. Cont.

\begin{tabular}{|c|c|c|c|c|}
\hline$\#$. & & Strategy & Measures & References \\
\hline 98 & \multirow{21}{*}{ 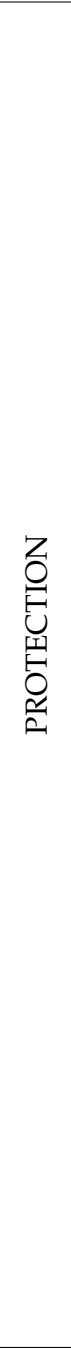 } & \multirow{4}{*}{$\begin{array}{l}\text { Protect crops from } \\
\text { water scarcity }\end{array}$} & $\begin{array}{c}\text { Viticulture: Changes in cultural practices and driving systems, } \\
\text { namely to optimize/reduce water consumption by the crop, } \\
\text { increasing the efficiency of water use }\end{array}$ & [200] \\
\hline 99 & & & Anticipation or delay of sowing according to the climate & [18] \\
\hline 100 & & & Punctual/ deficit irrigation & {$[189,231]$} \\
\hline 101 & & & Permanent irrigation & {$[232,233]$} \\
\hline 102 & & \multirow[t]{2}{*}{$\begin{array}{l}\text { Protect the farm against } \\
\text { floods }\end{array}$} & $\begin{array}{l}\text { Promote the cleaning and normalization of water lines, } \\
\text { involving technical training and taking into account the } \\
\text { maintenance of riparian vegetation }\end{array}$ & {$[234,235]$} \\
\hline 103 & & & Natural Flood Management & {$[236,237]$} \\
\hline 104 & & $\begin{array}{l}\text { Increase forage stocks } \\
\quad \text { (in good years) }\end{array}$ & Increase hay and straw stock (in good years) & [18] \\
\hline 105 & & \multirow{4}{*}{ Fire protection } & $\begin{array}{l}\text { Improve Forest Fire Management (Fire Prevention; Fire } \\
\text { Detection; Initial attack; Fuel management) }\end{array}$ & [236] \\
\hline 106 & & & Fire breaks; Fuel breaks and Green belts & [237] \\
\hline 107 & & & Promoting heterogeneous agro-forest mosaics & [238] \\
\hline 108 & & & Strategic Forest Planning at Landscape level & [239-241] \\
\hline 109 & & \multirow{2}{*}{$\begin{array}{l}\text { Protect from storms } \\
\text { and strong winds }\end{array}$} & Increase the strength of greenhouses and structures & [242] \\
\hline 110 & & & Use stronger tutors for plants & [18] \\
\hline 111 & & \multirow{3}{*}{$\begin{array}{l}\text { Protect crops and } \\
\text { animals from heat } \\
\text { waves }\end{array}$} & Use sprinkler and fogging to reduce the temperature & [242] \\
\hline 112 & & & Install artificial shade & [242] \\
\hline 113 & & & $\begin{array}{c}\text { Strengthening of environmental control equipment in protected } \\
\text { cultures (cooling's, etc.) }\end{array}$ & [242] \\
\hline 114 & & \multirow{3}{*}{$\begin{array}{l}\text { Fight plagues and } \\
\text { diseases }\end{array}$} & Fight plagues with application of plant based pesticides & {$[117,243]$} \\
\hline 115 & & & Fight plagues (e.g., P. Cinnamomi) with manure application & {$[115,116]$} \\
\hline 116 & & & Installing pest traps & [244] \\
\hline 117 & & $\begin{array}{l}\text { Protect crops from } \\
\text { water quality } \\
\text { degradation }\end{array}$ & water treatment or irrigation water (e.g., constructed wetlands) & [245] \\
\hline 118 & & Agricultural insurances & $\begin{array}{l}\text { Agricultural insurance against extreme events and production } \\
\text { losses }\end{array}$ & [246] \\
\hline 119 & \multirow{8}{*}{ 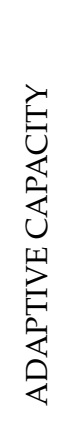 } & \multirow{8}{*}{ Promotion and Training } & $\begin{array}{l}\text { Rural extension/agricultural advice linked with } \\
\text { training/research/demonstration }\end{array}$ & \multirow{8}{*}{$\begin{array}{l}{[19,69,123,129,} \\
247,248]\end{array}$} \\
\hline 120 & & & $\begin{array}{l}\text { Training of public administration and private sector technicians } \\
\text { in this area }\end{array}$ & \\
\hline 121 & & & Rewarding Early Adopters & \\
\hline 122 & & & Documenting and disseminating good traditional practices & \\
\hline 123 & & & Environmental education (e.g., in schools) & \\
\hline 124 & & & Produce and disseminate more practical and useful knowledge & \\
\hline 125 & & & Establishment of demonstration centres for good practices & \\
\hline 126 & & & Promotion of landscape connectivity for species migration & \\
\hline 127 & \multirow{7}{*}{ 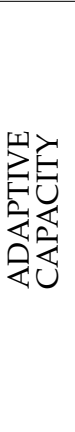 } & \multirow{7}{*}{$\begin{array}{l}\text { Research and } \\
\text { development }\end{array}$} & Increase knowledge of climate change scenarios & \multirow{7}{*}[19,64,69,96]{} \\
\hline 128 & & & Evaluation of new cultivars more adapted to climate change & \\
\hline 129 & & & $\begin{array}{l}\text { Classification of species and varieties in groups according to } \\
\text { their vegetative cycle and resistance to climatic factors }\end{array}$ & \\
\hline 130 & & & $\begin{array}{l}\text { Increase knowledge of the effectiveness of adaptation action } \\
\text { (actions and different contexts) }\end{array}$ & \\
\hline 131 & & & $\begin{array}{l}\text { Develop simpler technologies for the exploration of species of } \\
\text { natural resources more adapted to the future }\end{array}$ & \\
\hline 132 & & & Promote applied and interdisciplinary research & \\
\hline 133 & & & Creation of diagnostic tool to assess adaptation needs & \\
\hline
\end{tabular}


Table A1. Cont.

\begin{tabular}{|c|c|c|c|c|}
\hline \#. & & Strategy & Measures & References \\
\hline 134 & & & $\begin{array}{l}\text { Study of measures to adapt to situations of heat (extreme heat) } \\
\text { involving producer organizations and the scientific community }\end{array}$ & \\
\hline 135 & & & $\begin{array}{l}\text { Improvement of the meteorological system for warnings farmers } \\
\text { in case of such events }\end{array}$ & \\
\hline 136 & & & $\begin{array}{c}\text { Strengthening of the insurance system, particularly at the level } \\
\text { of agricultural installations and production }\end{array}$ & \\
\hline 137 & & & $\begin{array}{l}\text { Development of studies that identify areas of greater } \\
\text { vulnerability to extreme events with proposals to mitigate this } \\
\text { phenomenon }\end{array}$ & \\
\hline 138 & & & $\begin{array}{c}\text { Development/improvement of knowledge on indicators of the } \\
\text { water status of crops }\end{array}$ & \\
\hline 139 & & & $\begin{array}{l}\text { To deepen the knowledge of the genetic diversity of the forest, } \\
\text { plant and animal species, to promote the long-term conservation } \\
\text { of a broad genetic base and to ensure the availability of genetic } \\
\text { heritage and the production of reproductive material with the } \\
\text { characteristics and diversity appropriate to the needs of the } \\
\text { sectors, considering the expected impacts of climate change }\end{array}$ & \\
\hline 140 & \multirow{8}{*}{ 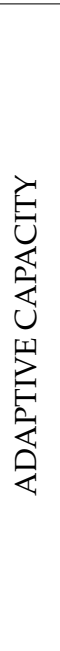 } & \multirow{8}{*}{ Policy } & $\begin{array}{l}\text { Changing the Decision-Making Environment (under which } \\
\text { management-level adaptation activities typically occur) }\end{array}$ & \multirow{8}{*}[19,64,69]{} \\
\hline 141 & & & $\begin{array}{l}\text { Compatibility/articulation between national and community } \\
\text { policies and different territorial management instruments }\end{array}$ & \\
\hline 142 & & & $\begin{array}{l}\text { Negotiating the inclusion of drought situations in the context of } \\
\text { the implementation of the EU Solidarity Fund }\end{array}$ & \\
\hline 143 & & & $\begin{array}{c}\text { Reinforce alert systems and create prevention and emergency } \\
\text { procedures }\end{array}$ & \\
\hline 144 & & & $\begin{array}{l}\text { Reinforce the mechanisms and instruments needed to improve } \\
\text { forest management and reduce abandonment }\end{array}$ & \\
\hline 145 & & & $\begin{array}{c}\text { Promote the carbon sequestration capacity of forest and } \\
\text { agricultural ecosystems }\end{array}$ & \\
\hline 146 & & & Promote diversification of products in forestry and farms & \\
\hline 147 & & & $\begin{array}{l}\text { Support systems for certification, promotion and marketing of } \\
\text { products with differentiated quality as well as innovation in this } \\
\text { area }\end{array}$ & \\
\hline 148 & \multirow{6}{*}{ 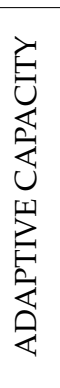 } & \multirow{6}{*}{ Governance } & $\begin{array}{c}\text { Promote local systemic vision in agricultural and regional } \\
\text { planning }\end{array}$ & \multirow{6}{*}[19,64,69]{} \\
\hline 149 & & & $\begin{array}{l}\begin{array}{l}\text { Reinforcing the mechanisms and instruments needed for forest } \\
\text { improvement }\end{array}\end{array}$ & \\
\hline 150 & & & Keeping population in rural areas & \\
\hline 151 & & & Promoting access to land and renewing farmers & \\
\hline 152 & & & $\begin{array}{l}\text { Strengthening the role of agriculture and forestry in protecting } \\
\text { soil and water }\end{array}$ & \\
\hline 153 & & & Adapt the governance system to the vision & \\
\hline 154 & \multirow{7}{*}{ 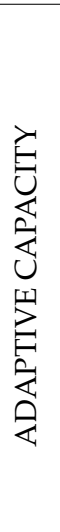 } & \multirow{6}{*}{ Financing } & $\begin{array}{l}\text { Pay farmers, pastoralists and foresters for their services to the } \\
\text { ecosystem and pay according to the services provided }\end{array}$ & \multirow{6}{*}[19,64,69]{} \\
\hline 155 & & & Develop and financially support investment in irrigation & \\
\hline 156 & & & $\begin{array}{l}\text { Support investment in, specifically, more efficient irrigation } \\
\text { systems, improved management and irrigation warning systems }\end{array}$ & \\
\hline 157 & & & $\begin{array}{c}\text { Creation of support for the maintenance of native species and } \\
\text { breeds as well as traditional varieties }\end{array}$ & \\
\hline 158 & & & $\begin{array}{l}\text { Financial support for prevention actions and reimbursement of } \\
\text { damages }\end{array}$ & \\
\hline 159 & & & $\begin{array}{c}\text { Creation of support for the maintenance of native species and } \\
\text { breeds as well as traditional varieties }\end{array}$ & \\
\hline 160 & & Monitoring & $\begin{array}{c}\text { Create environmental impact alert systems (using impact and } \\
\text { non-effect indicators) }\end{array}$ & {$[19,64,69]$} \\
\hline
\end{tabular}




\section{References}

1. UNFCCC Adaptation Knowledge Portal. Available online: http://www4.unfccc.int/sites/NWP/Pages/Home.aspx (accessed on 10 September 2018).

2. The Emissions Gap Report 2019; United Nations Environment Programme: Nairobi, Kenya, 2019; ISBN 978-92-807-3766-0.

3. IPCC. Annex III: Glossary. In Climate Change 2013: The Physical Science Basis. Contribution of Working Group I to the Fifth Assessment Report of the Intergovernmental Panel on Climate Change; Stocker, T.F., Qin, D., Plattner, G.-K., Tignor, M., Allen, S.K., Boschung, J., Nauels, A., Xia, Y., Bex, V., Midgley, P.M., Eds.; Cambridge University Press: Cambridge, UK; New York, NY, USA, 2013; pp. 1447-1466. ISBN 978-1-107-66182-0.

4. IPCC. Climate Change 2014: Impacts, Adaptation, and Vulnerability. Part A: Global and Sectoral Aspects. Contribution of Working Group II to the Fifth Assessment Report of the Intergovernmental Panel on Climate Change; Field, C.B., Barros, V.R., Dokken, D.J., Mach, K.J., Mastrandrea, M.D., Bilir, T.E., Chatterjee, M., Ebi, K.L., Estrada, Y.O., Genova, R.C., et al., Eds.; Cambridge University Press: Cambridge, UK; New York, NY, USA, 2014.

5. Hanewinkel, M.; Cullmann, D.A.; Schelhaas, M.-J.; Nabuurs, G.-J.; Zimmermann, N.E. Climate Change May Cause Severe Loss in the Economic Value of European Forest Land. Nat. Clim. Chang. 2013, 3, 203-207. [CrossRef]

6. Lee, C.; Schlemme, C.; Murray, J.; Unsworth, R. The Cost of Climate Change: Ecosystem Services and Wildland Fires. Ecol. Econ. 2015, 116, 261-269. [CrossRef]

7. Tol, R.S.J. The Economic Effects of Climate Change. J. Econ. Perspect. 2009, 23, 29-51. [CrossRef]

8. Del Pozo, A.; Brunel-Saldias, N.; Engler, A.; Ortega-Farias, S.; Acevedo-Opazo, C.; Lobos, G.A.; Jara-Rojas, R.; Molina-Montenegro, M.A. Climate Change Impacts and Adaptation Strategies of Agriculture in Mediterranean-Climate Regions (MCRs). Sustainability 2019, 11, 2769. [CrossRef]

9. Fischer, G.; Shah, M.; Tubiello, F.N.; Van Velhuizen, H. Socio-Economic and Climate Change Impacts on Agriculture: An Integrated Assessment, 1990-2080. Philos. Trans. R. Soc. B Biol. Sci. 2005, 360, 2067-2083. [CrossRef]

10. Beunen, R.; Opdam, P. When Landscape Planning Becomes Landscape Governance, What Happens to the Science? Landsc. Urban Plan. 2011, 100, 324-326. [CrossRef]

11. Campos, I.; Vizinho, A.; Coelho, C.; Alves, F.; Truninger, M.; Pereira, C.; Santos, F.D.; Penha Lopes, G. Participation, Scenarios and Pathways in Long-Term Planning for Climate Change Adaptation. Plan. Theory Pract. 2016, 1-20. [CrossRef]

12. Füssel, H.-M. Adaptation Planning for Climate Change: Concepts, Assessment Approaches, and Key Lessons. Sustain. Sci. 2007, 2, 265-275. [CrossRef]

13. Capela Lourenço, T. Changing Climate, Changing Decisions: Understanding Climate Adaptation Decision-Making and the Way Science Supports It. Ph.D. Thesis, Universidade de Lisboa, Lisbon, Portugal, 2015.

14. Preston, B.L.; Westaway, R.M.; Yuen, E.J. Climate Adaptation Planning in Practice: An Evaluation of Adaptation Plans from Three Developed Nations. Mitig. Adapt. Strateg. Glob. Chang. 2011, 16, 407-438. [CrossRef]

15. Andrade, C.; Fraga, H.; Santos, J.A. Climate Change Multi-Model Projections for Temperature Extremes in Portugal. Atmos. Sci. Lett. 2014, 15, 149-156. [CrossRef]

16. Nunes, J.P.; Seixas, J.; Pacheco, N.R. Vulnerability of Water Resources, Vegetation Productivity and Soil Erosion to Climate Change in Mediterranean Watersheds. Hydrol. Process. 2008, 22, 3115-3134. [CrossRef]

17. Han, E.; Ines, A.V.M.; Baethgen, W.E. Climate-Agriculture-Modeling and Decision Tool (CAMDT): A Software Framework for Climate Risk Management in Agriculture. Environ. Model. Softw. 2017, 95, 102-114. [CrossRef]

18. Smit, B.; Skinner, M.W. Adaptation Options in Agriculture to Climate Change: A Typology. Mitig. Adapt. Strateg. Glob. Chang. 2002, 7, 85-114. [CrossRef]

19. Howden, S.M.; Soussana, J.-F.; Tubiello, F.N.; Chhetri, N.; Dunlop, M.; Meinke, H. Adapting Agriculture to Climate Change. Proc. Natl. Acad. Sci. USA 2007, 104, 19691-19696. [CrossRef]

20. Barnett, J.; O'Neill, S. Maladaptation. Glob. Environ. Chang. 2010, 20, 211-213. [CrossRef]

21. Magnan, A.K.; Schipper, E.L.F.; Burkett, M.; Bharwani, S.; Burton, I.; Eriksen, S.; Gemenne, F.; Schaar, J.; Ziervogel, G. Addressing the Risk of Maladaptation to Climate Change. Wiley Interdiscip. Rev. Clim. Chang. 2016, 7, 646-665. [CrossRef]

22. Hernández-Morcillo, M.; Burgess, P.; Mirck, J.; Pantera, A.; Plieninger, T. Scanning Agroforestry-Based Solutions for Climate Change Mitigation and Adaptation in Europe. Environ. Sci. Policy 2018, 80, 44-52. [CrossRef]

23. Kristensen, P. The DPSIR framework. In Proceedings of the Workshop on a Comprehensive/Detailed Assessment of the Vulnerability of Water Resources to Environmental Change in Africa Using River Basin Approach, Nairobi, Kenya, 27-29 September 2004.

24. Kristensen, P. EEA Core Set of Indicators: Revised Version April 2003; European Environment Agency: Brussels, Belgium, 2003 ; p. 79.

25. Bours, D.; McGinn, C.; Pringle, P. Monitoring E Evaluation for Climate Change Adaptation: A Synthesis of Tools, Frameworks and Approaches; SEA Change CoP: Phnom Penh, Cambodia; UKCIP: Oxford, UK, 2013.

26. Fritzsche, K.; Schneiderbauer, S.; Bubeck, P.; Kienberger, S.; Buth, M.; Zebisch, M.; Kahlenborn, W. The Vulnerability Sourcebook: Concept and Guidelines for Standardised Vulnerability Assessments; Federal Ministry for Economic Cooperation and Development: Bonn, Germany, 2014.

27. Haasnoot, M.; Kwakkel, J.H.; Walker, W.E.; ter Maat, J. Dynamic Adaptive Policy Pathways: A Method for Crafting Robust Decisions for a Deeply Uncertain World. Glob. Environ. Chang. 2013, 23, 485-498. [CrossRef] 
28. Zandvoort, M.; Campos, I.S.; Vizinho, A.; Penha-Lopes, G.; Lorencová, E.K.; der Brugge, R.; van der Vlist, M.J.; den Brink, A.; Jeuken, A.B.M. Adaptation pathways in planning for uncertain climate change: Applications in Portugal, the Czech Republic and the Netherlands. Environ. Sci. Policy 2017, 78, 18-26. [CrossRef]

29. Venton, P.; La Trobe, S. Linking Climate Change Adaptation and Disaster Risk Reduction; Tearfund: Teddington, UK; Institute of Development Studies (IDS): Brighton and Hove, UK, 2008.

30. Mitter, H.; Schönhart, M.; Larcher, M.; Schmid, E. The Stimuli-Actions-Effects-Responses (SAER)-Framework for Exploring Perceived Relationships between Private and Public Climate Change Adaptation in Agriculture. J. Environ. Manag. 2018, 209, 286-300. [CrossRef]

31. Robert, M.; Thomas, A.; Bergez, J.-E. Processes of Adaptation in Farm Decision-Making Models. A Review. Agron. Sustain. Dev. 2016, 36, 64. [CrossRef]

32. Kurukulasuriya, P.; Rosenthal, S. Climate Change and Agriculture-A Review of Impacts and Adaptations; The World Bank Environment Department: Washington, DC, USA, 2003.

33. Regato, P.; IUCN Centre for Mediterranean Cooperation; Food and Agriculture Organization of the United Nations. Adapting to Global Change: Mediterranean Forests; IUCN Centre for Mediterranean Cooperation: Malaga, Spain, 2008; ISBN 978-2-8317-1098-3.

34. Vilà-Cabrera, A.; Coll, L.; Martínez-Vilalta, J.; Retana, J. Forest Management for Adaptation to Climate Change in the Mediterranean Basin: A Synthesis of Evidence. For. Ecol. Manag. 2018, 407, 16-22. [CrossRef]

35. Kottek, M.; Grieser, J.; Beck, C.; Rudolf, B.; Rubel, F. World Map of the Köppen-Geiger Climate Classification Updated. Meteorol. Z. 2006, 15, 259-263. [CrossRef]

36. Rubel, F.; Kottek, M. Observed and Projected Climate Shifts 1901-2100 Depicted by World Maps of the Köppen-Geiger Climate Classification. Meteorol. Z. 2010, 19, 135-141. [CrossRef]

37. Ramírez-Villegas, J.; Lau, C.; Köhler, A.-K.; Signer, J.; Jarvis, A.; Arnell, N.; Osborne, T.; Hooker, J. Climate Analogues: Finding Tomorrow's Agriculture Today; CGIAR Research Program on Climate Change, Agriculture and Food Security: Wageningen, The Netherlands, 2011.

38. Ruti, P.M.; Somot, S.; Giorgi, F.; Dubois, C.; Flaounas, E.; Obermann, A.; Dell'Aquila, A.; Pisacane, G.; Harzallah, A.; Lombardi, E.; et al. Med-CORDEX Initiative for Mediterranean Climate Studies. Bull. Am. Meteorol. Soc. 2015, 97, 1187-1208. [CrossRef]

39. Mariotti, A.; Pan, Y.; Zeng, N.; Alessandri, A. Long-Term Climate Change in the Mediterranean Region in the Midst of Decadal Variability. Clim. Dyn. 2015, 44, 1437-1456. [CrossRef]

40. Dubrovský, M.; Hayes, M.; Duce, P.; Trnka, M.; Svoboda, M.; Zara, P. Multi-GCM Projections of Future Drought and Climate Variability Indicators for the Mediterranean Region. Reg. Environ. Chang. 2014, 14, 1907-1919. [CrossRef]

41. Planton, S.; Lionello, P.; Artale, V.; Aznar, R.; Carrillo, A.; Colin, J.; Congedi, L.; Dubois, C.; Elizalde, A.; Gualdi, S.; et al. The Climate of the Mediterranean Region in Future Climate Projections. In The Climate of the Mediterranean Region; Lionello, P., Ed.; Elsevier: Oxford, UK, 2012; Chapter 8; pp. 449-502. ISBN 978-0-12-416042-2.

42. IPMA Portal Do Clima. Available online: http:/ / www.portaldoclima.pt/pt/ (accessed on 26 July 2016).

43. Bedia, J.; Herrera, S.; Camia, A.; Moreno, J.M.; Gutiérrez, J.M. Forest Fire Danger Projections in the Mediterranean Using ENSEMBLES Regional Climate Change Scenarios. Clim. Chang. 2014, 122, 185-199. [CrossRef]

44. Khabarov, N.; Krasovskii, A.; Obersteiner, M.; Swart, R.; Dosio, A.; San-Miguel-Ayanz, J.; Durrant, T.; Camia, A.; Migliavacca, M. Forest Fires and Adaptation Options in Europe. Reg. Environ. Chang. 2016, 16, 21-30. [CrossRef]

45. Moriondo, M.; Good, P.; Durao, R.; Bindi, M.; Giannakopoulos, C.; Corte-Real, J. Potential Impact of Climate Change on Fire Risk in the Mediterranean Area. Clim. Res. 2006, 31, 85-95. [CrossRef]

46. Bennett, J.M.; Calosi, P.; Clusella-Trullas, S.; Martínez, B.; Sunday, J.; Algar, A.C.; Araújo, M.B.; Hawkins, B.A.; Keith, S.; Kühn, I. GlobTherm, a Global Database on Thermal Tolerances for Aquatic and Terrestrial Organisms. Sci. Data 2018, 5, 180022. [CrossRef]

47. Pecl, G.T.; Araújo, M.B.; Bell, J.D.; Blanchard, J.; Bonebrake, T.C.; Chen, I.-C.; Clark, T.D.; Colwell, R.K.; Danielsen, F.; Evengård, B.; et al. Biodiversity Redistribution under Climate Change: Impacts on Ecosystems and Human Well-Being. Science 2017, 355, eaai9214. [CrossRef]

48. Barredo, J.I.; Caudullo, G.; Dosio, A. Mediterranean Habitat Loss under Future Climate Conditions: Assessing Impacts on the Natura 2000 Protected Area Network. Appl. Geogr. 2016, 75, 83-92. [CrossRef]

49. Araújo, M.B.; Alagador, D.; Cabeza, M.; Nogués-Bravo, D.; Thuiller, W. Climate Change Threatens European Conservation Areas. Ecol. Lett. 2011, 14, 484-492. [CrossRef] [PubMed]

50. Klausmeyer, K.R.; Shaw, M.R. Climate Change, Habitat Loss, Protected Areas and the Climate Adaptation Potential of Species in Mediterranean Ecosystems Worldwide. PLoS ONE 2009, 4, e6392. [CrossRef]

51. Thuiller, W.; Lavorel, S.; Araújo, M.B.; Sykes, M.T.; Prentice, I.C. Climate Change Threats to Plant Diversity in Europe. Proc. Natl. Acad. Sci. USA 2005, 102, 8245-8250. [CrossRef]

52. Do Rosário, L. Indicadores de Desertificação Para Portugal Continental; DGRF-Direcção-Geral dos Recursos Florestais: Lisbon, Portugal, 2004.

53. European Commission. Joint Research Centre. World Atlas of Desertification: Rethinking Land Degradation and Sustainable Land Management; Publications Office: Luxembourg, 2018.

54. García-Ruiz, J.M.; López-Moreno, J.I.; Vicente-Serrano, S.M.; Lasanta-Martínez, T.; Beguería, S. Mediterranean Water Resources in a Global Change Scenario. Earth Sci. Rev. 2011, 105, 121-139. [CrossRef] 
55. Giannakopoulos, C.; Le Sager, P.; Bindi, M.; Moriondo, M.; Kostopoulou, E.; Goodess, C.M. Climatic Changes and Associated Impacts in the Mediterranean Resulting from a 2 C Global Warming. Glob. Planet. Chang. 2009, 68, 209-224. [CrossRef]

56. Iglesias, A.; Garrote, L.; Flores, F.; Moneo, M. Challenges to Manage the Risk of Water Scarcity and Climate Change in the Mediterranean. Water Resour. Manag. 2007, 21, 775-788. [CrossRef]

57. Lionello, P.; Abrantes, F.; Gacic, M.; Planton, S.; Trigo, R.; Ulbrich, U. The Climate of the Mediterranean Region: Research Progress and Climate Change Impacts. Reg. Environ. Chang. 2014, 14, 1679-1684. [CrossRef]

58. Millán, M.M.; Estrela, M.J.; Sanz, M.J.; Mantilla, E.; Martín, M.; Pastor, F.; Salvador, R.; Vallejo, R.; Alonso, L.; Gangoiti, G.; et al. Climatic Feedbacks and Desertification: The Mediterranean Model. J. Clim. 2005, 18, 684-701. [CrossRef]

59. Nunes, J.P.; Jacinto, R.; Keizer, J.J. Combined Impacts of Climate and Socio-Economic Scenarios on Irrigation Water Availability for a Dry Mediterranean Reservoir. Sci. Total Environ. 2017, 584-585, 219-233. [CrossRef] [PubMed]

60. Wiebe, K.; Lotze-Campen, H.; Sands, R.; Tabeau, A.; van der Mensbrugghe, D.; Biewald, A.; Bodirsky, B.; Islam, S.; Kavallari, A.; Mason-D'Croz, D.; et al. Climate Change Impacts on Agriculture in 2050 under a Range of Plausible Socioeconomic and Emissions Scenarios. Environ. Res. Lett. 2015, 10, 085010. [CrossRef]

61. De Ferreira, D.B. Evoluçao Da Paisagem de Montado No Alentejo Interior Ao Longo Do Século XX: Dinâmica e Incidências Ambientais. Finisterra Rev. Port. Geogr. 2001, 36, 179-193. [CrossRef]

62. Oliveira, A.; Correia, A.V. Principais Espécies Florestais Com Interesse Para Portugal, Zonas de Influência Atlântica; Estudos e Informação No 322; Direcção-Geral das Florestas: Lisbon, Portugal, 2003.

63. Pinto-Correia, T.; Ribeiro, N.; Sá-Sousa, P. Introducing the Montado, the Cork and Holm Oak Agroforestry System of Southern Portugal. Agrofor. Syst. 2011, 82, 99. [CrossRef]

64. MAMAOT. Estratégia de Adaptação Agricultura e Floresta Às Alterações Climáticas—Portugal Continental (Fase 1); APA-Agência Portuguesa do Ambiente: Lisbon, Portugal, 2013.

65. Kindon, S.; Pain, R.; Kesby, M. Participatory Action Research Approaches and Methods: Connecting People, Participation and Place; Routledge: Abingdon-on-Thames, UK, 2007; Volume 22.

66. McIntyre, A. Participatory Action Research; SAGE Publications: Thousand Oaks, CA, USA, 2007; Volume 52.

67. Climate-Adapt Home-Climate-ADAPT. Available online: https:/ / climate-adapt.eea.europa.eu/ (accessed on 10 September 2018).

68. CIRCLE2 Infobase CIRCLE2-Climate Adaptation Research Infobase. Available online: http://infobase.circle-era.eu/search.jsp (accessed on 10 September 2018).

69. Vizinho, A.; Avelar, D.; Campos, I.; Fonseca, A.; Penha-Lopes, G. BASE-Bottom-up adaptation strategies for a sustainable Europe. In Proceedings of the Report of Participatory State of the Art on Adaptation to Climate Change in Alentejo, Beja, Portugal, 20 November 2013. [CrossRef]

70. Vizinho, A.; Campos, I.; Avelar, D.; Oliveira, H.F.C.; Cruz, M.J.; Barreiro, R.; Fonseca, A.L.; Penha-Lopes, G.P. BASE-Bottom-up adaptation strategies for a sustainable Europe. In Proceedings of the Relatório do Workshop da Avaliação Multicritério das Medidas de Adaptação à Alterações Climáticas da Agricultura e Florestas do Alentejo, Beja, Portugal, 27 November 2014. [CrossRef]

71. Tscherning, K.; Helming, K.; Krippner, B.; Sieber, S.; Paloma, S.G. y Does Research Applying the DPSIR Framework Support Decision Making? Land Use Policy 2012, 29, 102-110. [CrossRef]

72. Eisenack, K.; Stecker, R. An Action Theory of Adaptation to Climate Change; Earth System Governance: Utrecht, The Netherlands, 2010.

73. Khajuria, A.; Ravindranath, N.H. Climate Change Vulnerability Assessment: Approaches DPSIR Framework and Vulnerability Index. J. Earth Sci. Clim. Chang. 2012, 3. [CrossRef]

74. Vizinho, A.; Campos, I.; Coelho, C.; Pereira, C.; Roebeling, P.; Alves, F.; Rocha, J.; Alves, M.F.; Santos, F.D.; Penha-lopes, G. SWAP_Planeamento Participativo da Adaptação Costeira às Alterações Climáticas. Rev. Gestão Costeira Integr. 2017, 17, 99-116. [CrossRef]

75. Parry, M.; Parry, M.L.; Canziani, O.; Palutikof, J.; Van der Linden, P.; Hanson, C. Climate Change 2007-Impacts, Adaptation and Vulnerability: Working Group II Contribution to the Fourth Assessment Report of the IPCC; Cambridge University Press: Cambridge, UK, 2007; Volume 4.

76. Verchot, L.V.; Van Noordwijk, M.; Kandji, S.; Tomich, T.; Ong, C.; Albrecht, A.; Mackensen, J.; Bantilan, C.; Anupama, K.V.; Palm, C. Climate Change: Linking Adaptation and Mitigation through Agroforestry. Mitig. Adapt. Strateg. Glob. Chang. 2007, 12, 901-918. [CrossRef]

77. Klein, R.J.; Schipper, E.L.F.; Dessai, S. Integrating Mitigation and Adaptation into Climate and Development Policy: Three Research Questions. Environ. Sci. Policy 2005, 8, 579-588. [CrossRef]

78. Rosenzweig, C.; Tubiello, F.N. Adaptation and Mitigation Strategies in Agriculture: An Analysis of Potential Synergies. Mitig. Adapt. Strateg. Glob. Chang. 2007, 12, 855-873. [CrossRef]

79. Biesbroek, G.R.; Swart, R.J.; Van der Knaap, W.G. The Mitigation-Adaptation Dichotomy and the Role of Spatial Planning. Habitat Int. 2009, 33, 230-237. [CrossRef]

80. Davoudi, S.; Crawford, J.; Mehmood, A. Planning for Climate Change: Strategies for Mitigation and Adaptation for Spatial Planners; Routledge: Abingdon-on-Thames, UK, 2009; ISBN 978-1-136-57400-9.

81. Laukkonen, J.; Blanco, P.K.; Lenhart, J.; Keiner, M.; Cavric, B.; Kinuthia-Njenga, C. Combining Climate Change Adaptation and Mitigation Measures at the Local Level. Habitat Int. 2009, 33, 287-292. [CrossRef] 
82. Smith, P.; Olesen, J.E. Synergies between the Mitigation of, and Adaptation to, Climate Change in Agriculture. J. Agric. Sci. 2010, 148, 543-552. [CrossRef]

83. Engle, N.L. Adaptive Capacity and Its Assessment. Glob. Environ. Chang. 2011, 21, 647-656. [CrossRef]

84. Edenhofer, O.; Pichs-Madruga, R.; Sokona, Y.; Kadner, S.; Minx, J.C.; Brunner, S.; Agrawala, S.; Baiocchi, G.; Bashmakov, I.A.; Blanco, G.; et al. Technical Summary. In Climate Change 2014: Mitigation of Climate Change. Contribution of Working Group III to the Fifth Assessment Report of the Intergovernmental Panel on Climate Change; Edenhofer, O., Pichs-Madruga, R., Sokona, Y., Farahani, E., Kadner, S., Seyboth, K., Adler, A., Baum, I., Brunner, S., Eickemeier, P., et al., Eds.; Cambridge University Press: Cambridge, UK; New York, NY, USA, 2014.

85. Vilén, T.; Fernandes, P.M. Forest Fires in Mediterranean Countries: CO2 Emissions and Mitigation Possibilities through Prescribed Burning. Environ. Manag. 2011, 48, 558-567. [CrossRef]

86. Lal, R. Soil Carbon Sequestration to Mitigate Climate Change. Geoderma 2004, 123, 1-22. [CrossRef]

87. Van der Werf, G.R.; Morton, D.C.; DeFries, R.S.; Olivier, J.G.J.; Kasibhatla, P.S.; Jackson, R.B.; Collatz, G.J.; Randerson, J.T. CO 2 Emissions from Forest Loss. Nat. Geosci. 2009, 2, 737-738. [CrossRef]

88. Beukes, P.C.; Gregorini, P.; Romera, A.J.; Levy, G.; Waghorn, G.C. Improving Production Efficiency as a Strategy to Mitigate Greenhouse Gas Emissions on Pastoral Dairy Farms in New Zealand. Agric. Ecosyst. Environ. 2010, 136, 358-365. [CrossRef]

89. Wilken, G.C. Microclimate Management by Traditional Farmers. Geogr. Rev. 1972, 62, 544-560. [CrossRef]

90. Príncipe, A.; Nunes, A.; Pinho, P.; do Rosário, L.; Correia, O.; Branquinho, C. Modeling the Long-Term Natural Regeneration Potential of Woodlands in Semi-Arid Regions to Guide Restoration Efforts. Eur. J. For. Res. 2014. [CrossRef]

91. Skidmore, E.L.; Hagen, L.J. Evaporation in Sheltered Areas as Influenced by Windbreak Porosity. Agric. Meteorol. 1970, 7, 363-374. [CrossRef]

92. Pulido, F.J.; Díaz, M. Regeneration of a Mediterranean Oak: A Whole-Cycle Approach. Ecoscience 2005, 12, 92-102. [CrossRef]

93. Raeissi, S.; Taheri, M. Energy Saving by Proper Tree Plantation. Build. Environ. 1999, 34, 565-570. [CrossRef]

94. Smit, C.; den Ouden, J.; Díaz, M. Facilitation of Quercus Ilex Recruitment by Shrubs in Mediterranean Open Woodlands. J. Veg. Sci. 2007, 19, 193-200. [CrossRef]

95. Aussenac, G. Interactions between Forest Stands and Microclimate: Ecophysiological Aspects and Consequences for Silviculture. Ann. For. Sci. 2000, 57, 287-301. [CrossRef]

96. Nelson, D.R. Adaptation and Resilience: Responding to a Changing Climate. Wiley Interdiscip. Rev. Clim. Chang. 2011, 2, 113-120. [CrossRef]

97. Santos, F.D.; Miranda, P. Alterações Climáticas Em Portugal. Cenários, Impactos e Medidas de Adaptação-Projecto SIAM II; Gradiva: Lisbon, Portugal, 2006.

98. Pandey, D.N.; Gupta, A.K.; Anderson, D.M. Rainwater Harvesting as an Adaptation to Climate Change. Curr. Sci. 2003, 85, 46-59.

99. Ilstedt, U.; Bargués Tobella, A.; Bazié, H.R.; Bayala, J.; Verbeeten, E.; Nyberg, G.; Sanou, J.; Benegas, L.; Murdiyarso, D.; Laudon, H.; et al. Intermediate Tree Cover Can Maximize Groundwater Recharge in the Seasonally Dry Tropics. Sci. Rep. 2016, 6, 21930. [CrossRef]

100. Lancaster, B. Rainwater Harvesting for Drylands: Guiding Principles to Welcome Rain into Your Life and Landscape; Rainsource Press: White River Junction, VT, USA, 2006; ISBN 978-0-9772464-0-3.

101. Yuen, E.; Anda, M.; Mathew, K.; Ho, G. Water Harvesting Techniques for Small Communities in Arid Areas. Water Sci. Technol. 2001, 44, 189-195. [CrossRef]

102. Rashid, M.; Alvi, S.; Kausar, R.; Akram, M.I. The Effectiveness of Soil and Water Conservation Terrace Structures for Improvement of Crops and Soil Productivity in Rainfed Terraced System. Pak. J. Agric. Sci. 2016, 53, 241-248.

103. Zougmoré, R.; Jalloh, A.; Tioro, A. Climate-Smart Soil Water and Nutrient Management Options in Semiarid West Africa: A Review of Evidence and Analysis of Stone Bunds and Zaï Techniques. Agric. Food Secur. 2014, 3, 16. [CrossRef]

104. Chalker-Scott, L. Impact of Mulches on Landscape Plants and the Environment-A Review. J. Environ. Hortic. 2007, 25, 239. [CrossRef]

105. Castellini, M.; Giglio, L.; Niedda, M.; Palumbo, A.D.; Ventrella, D. Impact of Biochar Addition on the Physical and Hydraulic Properties of a Clay Soil. Soil Tillage Res. 2015, 154, 1-13. [CrossRef]

106. Liu, M.; Li, Z.; Ren, W. Research on the Effect of Waterboxx Technology on Haloxylon Ammodendron Afforestation in Arid and Semiarid Areas. Available online: https://www.ingentaconnect.com/content/asp/asem/2014/00000006/00000002/art00013 (accessed on 27 February 2020).

107. Kumar, B.M. Agroforestry: The New Old Paradigm for Asian Food Security. J. Trop. Agric. 2007, 44, 1-14.

108. Nguyen, Q.; Hoang, M.H.; Öborn, I.; van Noordwijk, M. Multipurpose Agroforestry as a Climate Change Resiliency Option for Farmers: An Example of Local Adaptation in Vietnam. Clim. Chang. 2013, 117, 241-257. [CrossRef]

109. Gurr, G.M.; Wratten, S.D.; Luna, J.M. Multi-Function Agricultural Biodiversity: Pest Management and Other Benefits. Basic Appl. Ecol. 2003, 4, 107-116. [CrossRef]

110. Hoffmann, A.A.; Sgrò, C.M. Climate Change and Evolutionary Adaptation. Nature 2011, 470, 479-485. [CrossRef] [PubMed]

111. Jump, A.S.; Marchant, R.; Peñuelas, J. Environmental Change and the Option Value of Genetic Diversity. Trends Plant Sci. 2009, 14, 51-58. [CrossRef]

112. Jump, A.S.; Peñuelas, J. Running to Stand Still: Adaptation and the Response of Plants to Rapid Climate Change. Ecol. Lett. 2005, 8, 1010-1020. [CrossRef] 
113. Lin, B.B. Resilience in Agriculture through Crop Diversification: Adaptive Management for Environmental Change. BioScience 2011, 61, 183-193. [CrossRef]

114. Domínguez Núñez, J.A.; Serrano, J.S.; Barreal, J.A.R.; González, J.A.S.D.O. The Influence of Mycorrhization with Tuber Melanosporum in the Afforestation of a Mediterranean Site with Quercus Ilex and Quercus Faginea. For. Ecol. Manag. 2006, 231, $226-233$. [CrossRef]

115. Aryantha, I.N.; Guest, D. Mycoparasitic and Antagonistic Inhibition on Phytophthora Cinnamomi Rands by Microbial Agents Isolated from Manure Composts. Plant Pathol. J. 2006, 5. [CrossRef]

116. Aryantha, I.P.; Cross, R.; Guest, D.I. Suppression of Phytophthora Cinnamomi in Potting Mixes Amended with Uncomposted and Composted Animal Manures. Phytopathology 2000, 90, 775-782. [CrossRef]

117. Neves, D.; Caetano, P.; Oliveira, J.; Maia, C.; Horta, M.; Sousa, N.; Salgado, M.; Dion?sio, L.; Magan, N.; Cravador, A. AntiPhytophthora Cinnamomi Activity of Phlomis Purpurea Plant and Root Extracts. Eur. J. Plant Pathol. 2014, 138, 835-846. [CrossRef]

118. Papanastasis, V.P.; Platis, P.D.; Dini-Papanastasi, O. Productivity of Deciduous Woody and Fodder Species in Relation to Air Temperature and Precipitation in a Mediterranean Environment. Agrofor. Syst. 1997, 37, 187-198. [CrossRef]

119. Morin, X.; Fahse, L.; Scherer-Lorenzen, M.; Bugmann, H. Tree Species Richness Promotes Productivity in Temperate Forests through Strong Complementarity between Species. Ecol. Lett. 2011, 14, 1211-1219. [CrossRef] [PubMed]

120. Yousefpour, R.; Thorsen, B.J. Risk and Uncertainty in Adaptive Forest Management under Climate Change. In Forest BioEnergy Production; Kellomäki, S., Kilpeläinen, A., Alam, A., Eds.; Springer: New York, NY, USA, 2013; pp. 223-238. ISBN 978-1-4614-8390-8.

121. Baudoin, W.; Nono-Womdim, R.; Lutaladio, N.; Hodder, A.; Castilla, N.; Leonardi, C.; Pascale, D.S.; Qaryouti, M.; Duffy, R. (Eds.) Good Agricultural Practices for Greenhouse Vegetable Crops: Principles for Mediterranean Climate Areas; FAO-Plant Production and Protection Paper; FAO: Rome, Italy, 2013.

122. FAO Guidelines for Good Forestry and Range Practices in Arid and Semi-Arid Zones of the Near East; Working Paper; FAO: Rome, Italy, 2009.

123. Shock, C.C.; Shock, C.B. Research, Extension, and Good Farming Practices Improve Water Quality and Productivity. J. Integr. Agric. 2012, 11, 14-30. [CrossRef]

124. Reque, J.A.; Martin, E. Designing Acorn Protection for Direct Seeding of Quercus Species in High Predation Areas. For. Syst. 2015, 24, 18. [CrossRef]

125. Alejano, R.; Tapias, R.; Fernández, M.; Torres, E.; Alaejos, J.; Domingo, J. Influence of Pruning and the Climatic Conditions on Acorn Production in Holm Oak (Quercus Ilex L.) Dehesas in SW Spain. Ann. For. Sci. 2008, 65, 209. [CrossRef]

126. Goldhamer, D.A.; Viveros, M. Effects of Preharvest Irrigation Cutoff Durations and Postharvest Water Deprivation on Almond Tree Performance. Irrig. Sci. 2000, 19, 125-131. [CrossRef]

127. Freduah, G.; Fidelman, P.; Smith, T.F. A Framework for Assessing Adaptive Capacity to Multiple Climatic and Non-Climatic Stressors in Small-Scale Fisheries. Environ. Sci. Policy 2019, 101, 87-93. [CrossRef]

128. Nelson, D.R.; Adger, W.N.; Brown, K. Adaptation to Environmental Change: Contributions of a Resilience Framework. Annu. Rev. Environ. Resour. 2007, 32, 395-419. [CrossRef]

129. Kruse, S.; Pütz, M. Adaptive Capacities of Spatial Planning in the Context of Climate Change in the European Alps. Eur. Plan. Stud. 2014, 22, 2620-2638. [CrossRef]

130. Universal Soil Loss Equation (USLE). Available online: http://www.omafra.gov.on.ca/english/engineer/facts/12-051.htm (accessed on 14 January 2015).

131. Dias, N.F.A. Sown Biodiverse Permanent Pastures Rich in Legumes as an Adaptation Tool against Climate Change; Universidade de Lisboa: Lisbon, Portugal, 2017.

132. Portuguese Low Carbon Roadmap -2050; APA—Agência Portuguesa do Ambiente: Lisbon, Portugal, 2019.

133. Van Passel, S.; Vanschoenwinkel, J.; Moretti, M. The Effect of Policy Leveraging Climate Change Adaptive Capacity in Agriculture. In Proceedings of the International Association of Agricultural Economists 2018 Conference, Vancouver, BC, Canada, 28 July-2 August 2018. [CrossRef]

134. Laird, D.A. The Charcoal Vision: A Win-Win-Win Scenario for Simultaneously Producing Bioenergy, Permanently Sequestering Carbon, While Improving Soil and Water Quality. Agron. J. 2008, 100, 178-181.

135. Matovic, D. Biochar as a Viable Carbon Sequestration Option: Global and Canadian Perspective. Energy 2011, 36, 2011-2016. [CrossRef]

136. Spokas, K.A.; Cantrell, K.B.; Novak, J.M.; Archer, D.W.; Ippolito, J.A.; Collins, H.P.; Boateng, A.A.; Lima, I.M.; Lamb, M.C.; McAloon, A.J.; et al. Biochar: A Synthesis of Its Agronomic Impact beyond Carbon Sequestration. J. Environ. Qual. 2012, 41, 973-989. [CrossRef]

137. Carrión-Prieto, P.; Hernández-Navarro, S.; Martín-Ramos, P.; Sánchez-Sastre, L.F.; Garrido-Laurnaga, F.; Marcos-Robles, J.L.; Martín-Gil, J. Mediterranean Shrublands as Carbon Sinks for Climate Change Mitigation: New Root-to-Shoot Ratios. Carbon Manag. 2017, 8, 67-77. [CrossRef]

138. Cañellas, I.; Sánchez-González, M.; Bogino, S.M.; Adame, P.; Moreno-Fernández, D.; Herrero, C.; Roig, S.; Tomé, M.; Paulo, J.A.; Bravo, F. Carbon sequestration in Mediterranean oak forests. In Managing Forest Ecosystems: The Challenge of Climate Change; Springer: Cham, Switzerland, 2017; pp. 403-427. 
139. Del Río, M.; Barbeito, I.; Bravo-Oviedo, A.; Calama, R.; Cañellas, I.; Herrero, C.; Montero, G.; Moreno-Fernández, D.; RuizPeinado, R.; Bravo, F. Mediterranean pine forests: Management effects on carbon stocks. In Managing Forest Ecosystems: The Challenge of Climate Change; Springer: Cham, Switzerlan, 2017; pp. 301-327.

140. Ruiz-Peinado, R.; Bravo-Oviedo, A.; López-Senespleda, E.; Bravo, F.; Del Rio, M. Forest Management and Carbon Sequestration in the Mediterranean Region: A Review. For. Syst. 2017, 26, eR04S. [CrossRef]

141. Zinn, Y.L. Carbon Sink Capacity: Soil Profile Characteristics. In Encyclopedia of Soil Science; CRC Press: Boca Raton, FL, USA, 2017; pp. 315-318.

142. Kay, B.D. Soil structure and organic carbon: A review. In Soil Processes and the Carbon Cycle; CRC Press: Boca Raton, FL, USA, 2018; pp. 169-197.

143. Teixeira, R.F.M. Sustainable Land Uses and Carbon Sequestration: The Case of Sown Biodiverse Permanent Pastures Rich in Legumes. Ph.D. Thesis, Universidade Técnica de Lisboa, Instituto Superior Técnico, Lisbon, Portugal, 2010.

144. Klumpp, K.; Chabbi, A.; Gastal, F.; Senapati, N.; Charrier, X.; Darsonville, O.; Creme, A. Carbon Sink Activity of Managed Grasslands. In Proceedings of the 19th EGU General Assembly Conference, Vienna, Austria, 23-28 April 2017; Volume 19, p. 13783.

145. Smith, P. Do Grasslands Act as a Perpetual Sink for Carbon? Glob. Chang. Biol. 2014, 20, 2708-2711. [CrossRef] [PubMed]

146. Chel, A.; Kaushik, G. Renewable Energy for Sustainable Agriculture. Agron. Sustain. Dev. 2011, 31, 91-118. [CrossRef]

147. Ominski, K.H.; Wittenberg, K.M. Strategies for reducing enteric methane emissions in forage-based beef production systems. In Climate Change and Managed Ecosystems; CRC Press: Boca Raton, FL, USA, 2005; pp. 261-272.

148. Beauchemin, K.A.; McAllister, T.A.; McGinn, S.M. Dietary Mitigation of Enteric Methane from Cattle. Cab Rev. Perspect. Agric. Vet. Sci. Nutr. Nat. Resour. 2009, 4, 1-18. [CrossRef]

149. Woods, J.; Williams, A.; Hughes, J.K.; Black, M.; Murphy, R. Energy and the Food System. Philos. Trans. R. Soc. B: Biol. Sci. 2010, 365, 2991-3006. [CrossRef]

150. Camargo, G.G.; Ryan, M.R.; Richard, T.L. Energy Use and Greenhouse Gas Emissions from Crop Production Using the Farm Energy Analysis Tool. BioScience 2013, 63, 263-273. [CrossRef]

151. Pimentel, D.; Williamson, S.; Alexander, C.E.; Gonzalez-Pagan, O.; Kontak, C.; Mulkey, S.E. Reducing Energy Inputs in the US Food System. Hum. Ecol. 2008, 36, 459-471. [CrossRef]

152. Khan, S.; Khan, M.A.; Hanjra, M.A.; Mu, J. Pathways to Reduce the Environmental Footprints of Water and Energy Inputs in Food Production. Food Policy 2009, 34, 141-149. [CrossRef]

153. Pattey, E.; Trzcinski, M.K.; Desjardins, R.L. Quantifying the Reduction of Greenhouse Gas Emissions as a Resultof Composting Dairy and Beef Cattle Manure. Nutr. Cycl. Agroecosyst. 2005, 72, 173-187. [CrossRef]

154. Huh, J.-H.; Kim, K.-Y. Time-Based Trend of Carbon Emissions in the Composting Process of Swine Manure in the Context of Agriculture 4.0. Processes 2018, 6, 168. [CrossRef]

155. Lockeretz, W. Energy Implications of Conservation Tillage. J. Soil Water Conserv. 1983, 38, $207-211$.

156. Tabatabaeefar, A.; Emamzadeh, H.; Varnamkhasti, M.G.; Rahimizadeh, R.; Karimi, M. Comparison of Energy of Tillage Systems in Wheat Production. Energy 2009, 34, 41-45. [CrossRef]

157. Mileusnić, Z.I.; Petrović, D.V.; Đević, M.S. Comparison of Tillage Systems According to Fuel Consumption. Energy 2010, 35, 221-228. [CrossRef]

158. Seemann, J.; Chirkov, Y.I.; Lomas, J.; Primault, B. Agrometeorology; Springer: Berlin/Heidelberg, Germany, 1979; ISBN 978-3-64267288-0.

159. Raftoyannis, Y.; Bredemeier, M.; Buozyte, R.; Lamersdorf, N.; Mavrogiakoumos, A.; Oddsdóttir, E.; Velichkov, I. Afforestation Strategies with Respect to Forest-Water Interactions. In Forest Management and the Water Cycle: An Ecosystem-Based Approach; Bredemeier, M., Cohen, S., Godbold, D.L., Lode, E., Pichler, V., Schleppi, P., Eds.; Ecological Studies; Springer: Dordrecht, The Netherlands, 2011; pp. 225-245. ISBN 978-90-481-9834-4.

160. Nunes, J.; Andrade, J.; Abreu, F.; Gazarini, L. Madeira Manuel Microclimatic Specificity of a Mediterranean Oak Woodland (Montado) in the Context of Global Change. Available online: http:/ /www.rdpc.uevora.pt/handle/10174/7677 (accessed on 26 October 2015).

161. Ollat, N.; Touzard, J.-M.; van Leeuwen, C. Climate Change Impacts and Adaptations: New Challenges for the Wine Industry. J. Wine Econ. 2016, 11, 139-149. [CrossRef]

162. Chirkov, Y.I. Microclimate and Phytoclimate. In Agrometeorology; Seemann, J., Chirkov, Y.I., Lomas, J., Primault, B., Eds.; Springer: Berlin/Heidelberg, Germany, 1979; pp. 139-141. ISBN 978-3-642-67288-0.

163. Gaffen, D.J.; Elliott, W.P.; Robock, A. Relationships between Tropospheric Water Vapor and Surface Temperature as Observed by Radiosondes. Geophys. Res. Lett. 1992, 19, 1839-1842. [CrossRef]

164. Farley, K.A.; Jobbágy, E.G.; Jackson, R.B. Effects of Afforestation on Water Yield: A Global Synthesis with Implications for Policy. Glob. Chang. Biol. 2005, 11, 1565-1576. [CrossRef]

165. Millán, M.M. Climate/water-cycle feedbacks in the Mediterranean: The role of land-use changes and the propagation of perturbations at the regional and global scale. In Regional Climate Variability and Its Impacts in the Mediterranean Area; Springer: Dordrecht, The Netherlands, 2007; pp. 83-101.

166. Millán, M.M. Extreme Hydrometeorological Events and Climate Change Predictions in Europe. J. Hydrol. 2014, 518, 206-224. [CrossRef] 
167. Agus, F.; Cassel, D.K.; Garrity, D.P. Soil-Water and Soil Physical Properties under Contour Hedgerow Systems on Sloping Oxisols. Soil Tillage Res. 1997, 40, 185-199. [CrossRef]

168. White, D.A.; Dunin, F.X.; Turner, N.C.; Ward, B.H.; Galbraith, J.H. Water Use by Contour-Planted Belts of Trees Comprised of Four Eucalyptus Species. Agric. Water Manag. 2002, 53, 133-152. [CrossRef]

169. Yeomans, P.A. Water for Every Farm Using the Keyline Plan; Second Back Row Press: Adelaide, Australia, 1981.

170. Thapa, B.B.; Cassel, D.K.; Garrity, D.P. Ridge Tillage and Contour Natural Grass Barrier Strips Reduce Tillage Erosion. Soil Tillage Res. 1999, 51, 341-356. [CrossRef]

171. Yalcin, H.; Cakir, E.; Aykas, E. Tillage Parameters and Economic Analysis of Direct Seeding, Minimum and Conventional Tillage in Wheat. J. Agron. 2005, 4, 329-332. [CrossRef]

172. Bhushan, L.; Ladha, J.K.; Gupta, R.K.; Singh, S.; Tirol-Padre, A.; Saharawat, Y.S.; Gathala, M.; Pathak, H. Saving of Water and Labor in a Rice-Wheat System with No-Tillage and Direct Seeding Technologies. Agron. J. 2007, 99, 1288-1296. [CrossRef]

173. Blevins, R.L.; Smith, M.S.; Thomas, G.W.; Frye, W.W. Influence of Conservation Tillage on Soil Properties. J. Soil Water Conserv. 1983, 38, 301-305.

174. Johnson, M.D.; Lowery, B.; Daniel, T.C. Soil Moisture Regimes of Three Conservation Tillage Systems. Trans. ASAE 1984, 27, 1385-1390. [CrossRef]

175. Gallaher, R.N. Soil Moisture Conservation and Yield of Crops No-Till Planted in Rye. Soil Sci. Soc. Am. J. 1977, 41, 145-147. [CrossRef]

176. McGuire, A.M.; Bryant, D.C.; Denison, R.F. Wheat Yields, Nitrogen Uptake, and Soil Moisture Following Winter Legume Cover Crop vs. Fallow. Agron. J. 1998, 90, 404-410. [CrossRef]

177. Ghuman, B.S.; Sur, H.S. Effect of Manuring on Soil Properties and Yield of Rainfed Wheat. J. Indian Soc. Soil Sci. $2006,54,6-11$.

178. Shi, Z.-H.; Chen, L.-D.; Cai, C.-F.; Li, Z.-X.; Liu, G.-H. Effects of Long-Term Fertilization and Mulch on Soil Fertility in Contour Hedgerow Systems: A Case Study on Steeplands from the Three Gorges Area, China. Nutr. Cycl. Agroecosyst. 2009, 84, 39-48. [CrossRef]

179. Munn, D.A. Comparisons of Shredded Newspaper and Wheat Straw as Crop Mulches. HortTechnology 1992, 2, 361-366. [CrossRef]

180. Pattanayak, S.; Evan Mercer, D. Valuing Soil Conservation Benefits of Agroforestry: Contour Hedgerows in the Eastern Visayas, Philippines. Agric. Econ. 1998, 18, 31-46. [CrossRef]

181. Prinz, D. Water harvesting-Past and future. In Sustainability of Irrigated Agriculture; Springer: Dordrecht, The Netherlands, 1996; pp. 137-168.

182. Kitching, R.; Edmunds, W.M.; Shearer, T.R.; Walton, N.R.G.; Jacovides, J. Assessment of Recharge to Aquifers / Evaluation de Recharge d'aquifères. Hydrol. Sci. Bull. 1980, 25, 217-235. [CrossRef]

183. Cooper, J.D.; Gardner, C.M.K.; Mackenzie, N. Soil Controls on Recharge to Aquifers. J. Soil Sci. 1990, 41, 613-630. [CrossRef]

184. Petkov, P.; Petrova, R.; Markov, N.; Gadzhalska, N.; Kireva, R.; Chekhlarova, S.; Karaivanov, K. Good practices for irrigation of agricultural crops. Agric. Eng. 2009, 46, 32-39.

185. El Baki, H.M.A.; Fujimaki, H.; Tokumoto, I.; Saito, T. Optimizing Irrigation Depth Using a Plant Growth Model and Weather Forecast. J. Agric. Sci. 2018, 10, 1-12. [CrossRef]

186. Serra-Wittling, C.; Molle, B.; Cheviron, B. Plot Level Assessment of Irrigation Water Savings Due to the Shift from Sprinkler to Localized Irrigation Systems or to the Use of Soil Hydric Status Probes. Application in the French Context. Agric. Water Manag. 2019, 223, 105682. [CrossRef]

187. Al-Busaidi, A.; Ahmed, M.; Shaharoona, B. Evaluating Continuous Application of Treated Sludge on Soil and Plant Productivity. J. Agric. Mar. Sci. 2017, 22, 2-7. [CrossRef]

188. Libutti, A.; Gatta, G.; Gagliardi, A.; Vergine, P.; Pollice, A.; Beneduce, L.; Disciglio, G.; Tarantino, E. Agro-Industrial Wastewater Reuse for Irrigation of a Vegetable Crop Succession under Mediterranean Conditions. Agric. Water Manag. 2018, 196, 1-14. [CrossRef]

189. Westley, S.B. Living Fences: A Close-up Look at an Agroforestry Technology. Agrofor. Today (Kenya) 1990, 2, 11-13.

190. Martin, F.W. Living Fence - Its Role on the Small Farm; ECHOnet: North Fort Myers, FL, USA, 1991; p. 11.

191. Otsyina, R.M.; Norton, B.W.; Djimde, M. Fodder Trees and Shrubs in Arid and Semi-Arid Livestock Production Systems. In Proceedings of the XVIII International Grassland Congress, Winnepeg, MB, Canada, 8-17 June 1997; Volume 2, pp. $429-438$.

192. Ben Salem, H.; Nefzaoui, A.; Ben Salem, L. Opuntia Ficus-Indica f. Inermis and Atriplex Nummularia L.: Two Complementary Fodder Shrubs for Sheep and Goats. In Proceedings of the IV International Congress on Cactus Pear and Cochineal 581, Hammamet, Tunisia, 22 October 2000; pp. 333-341.

193. Heraty, J. Parasitoid Biodiversity and Insect Pest Management. Insect Biodivers. Sci. Soc. 2017, 603-625. [CrossRef]

194. Altieri, M.; Nicholls, C. Biodiversity and Pest Management in Agroecosystems; CRC Press: Boca Raton, FL, USA, 2018.

195. Brévault, T.; Clouvel, P. Pest Management: Reconciling Farming Practices and Natural Regulations. Crop Prot. 2019, 115, 1-6. [CrossRef]

196. Castellano, R.L.S.; Moroney, J. Farming Adaptations in the Face of Climate Change. Renew. Agric. Food Syst. $2018,33,206-211$. [CrossRef]

197. Stella, A.; Nicolazzi, E.L.; Van Tassell, C.P.; Rothschild, M.F.; Colli, L.; Rosen, B.D.; Sonstegard, T.S.; Crepaldi, P.; Tosser-Klopp, G.; Joost, S.; et al. AdaptMap: Exploring Goat Diversity and Adaptation. Genet. Sel. Evol. 2018, 50, 61. [CrossRef] 
198. Jouven, M.; Carrere, P.; Baumont, R. Model Predicting Dynamics of Biomass, Structure and Digestibility of Herbage in Managed Permanent Pastures. 1. Model Description. Grass Forage Sci. 2006, 61, 112-124. [CrossRef]

199. Costa, J.M.; Vaz, M.; Escalona, J.; Egipto, R.; Lopes, C.; Medrano, H.; Chaves, M.M. Modern Viticulture in Southern Europe: Vulnerabilities and Strategies for Adaptation to Water Scarcity. Agric. Water Manag. 2016, 164, 5-18. [CrossRef]

200. Vacante, V.; Kreiter, S. Handbook of Pest Management in Organic Farming; CABI: Oxford, UK, 2017; ISBN 978-1-78064-499-8.

201. Pellegrino, E.; Bedini, S.; Avio, L.; Bonari, E.; Giovannetti, M. Field Inoculation Effectiveness of Native and Exotic Arbuscular Mycorrhizal Fungi in a Mediterranean Agricultural Soil. Soil Biol. Biochem. 2011, 43, 367-376. [CrossRef]

202. Pardini, A. A Perspective on the Valorization of Agro-Silvo-Pastoral Systems in the Mediterranean Basin. Pastos Y Forrajes 2007, 30, 30 .

203. Pardini, A.; Nori, M. Agro-Silvo-Pastoral Systems in Italy: Integration and Diversification. Pastoralism 2011, 1, 26. [CrossRef]

204. Pinto-Correia, T.; Ribeiro, N.; GOdinho, S. Sistemas Silvopastorales en Portugal: Perspectivas para o Montado, um Sistema Multifunctional. Available online: http:/ / dspace.uevora.pt/rdpc/handle/10174/8151 (accessed on 27 February 2020).

205. Bagella, S.; Caria, M.C.; Farris, E.; Rossetti, I.; Filigheddu, R. Traditional Land Uses Enhanced Plant Biodiversity in a Mediterranean Agro-Silvo-Pastoral System. Plant Biosyst. Int. J. Deal. All Asp. Plant Biol. 2016, 150, 201-207. [CrossRef]

206. Martín-Forés, I. Exotic Plant Species in the Mediterranean Biome: A Reflection of Cultural and Historical Relationships. Mediterr. Identities Environ. Soc. Cult. 2017, 179-201. [CrossRef]

207. Nath, C.D.; Schroth, G.; Burslem, D.F.R.P. Why Do Farmers Plant More Exotic than Native Trees? A Case Study from the Western Ghats, India. Agric. Ecosyst. Environ. 2016, 230, 315-328. [CrossRef]

208. Hijmans, R.J.; Graham, C.H. The Ability of Climate Envelope Models to Predict the Effect of Climate Change on Species Distributions. Glob. Chang. Biol. 2006, 12, 2272-2281. [CrossRef]

209. Polechová, J.; Barton, N.; Marion, G.; Rice, A.E.S.H.; Whitlock, E.M.C. Species' Range: Adaptation in Space and Time. Am. Nat. 2009, 174, E186-E204. [CrossRef]

210. Ceccarelli, S.; Grando, S.; Maatougui, M.; Michael, M.; Slash, M.; Haghparast, R.; Rahmanian, M.; Taheri, A.; Al-Yassin, A.; Benbelkacem, A. Plant Breeding and Climate Changes. J. Agric. Sci. 2010, 148, 627-637. [CrossRef]

211. Mackill, D.J.; Ismail, A.M.; Kumar, A.; Gregorio, G.B. The Role of Stress-Tolerant Varieties for Adapting to Climate Change; CEEDIN: Curitiba, Brazil, 2010; pp. 31-33.

212. Fraga, H.; Santos, J.A.; Malheiro, A.C.; Oliveira, A.A.; Moutinho-Pereira, J.; Jones, G.V. Climatic Suitability of Portuguese Grapevine Varieties and Climate Change Adaptation. Int. J. Climatol. 2016, 36, 1-12. [CrossRef]

213. Fraser, E.D.G.; Simelton, E.; Termansen, M.; Gosling, S.N.; South, A. "Vulnerability Hotspots": Integrating Socio-Economic and Hydrological Models to Identify Where Cereal Production May Decline in the Future Due to Climate Change Induced Drought. Agric. For. Meteorol. 2013, 170, 195-205. [CrossRef]

214. Hoffmann, I. Adaptation to Climate Change-Exploring the Potential of Locally Adapted Breeds. Animal 2013, 7, 346-362. [CrossRef] [PubMed]

215. Braga, R.; Pinto, P.A. Alterações Climáticas e Agricultura. Inov. Tecnol. Form. Agríc. 2009, 12, $34-56$.

216. Libby, W.J.; Rauter, R.M. Advantages of Clonal Forestry. For. Chron. 1984, 60, 145-149. [CrossRef]

217. Prober, S.M.; Thiele, K.R.; Rundel, P.W.; Yates, C.J.; Berry, S.L.; Byrne, M.; Christidis, L.; Gosper, C.R.; Grierson, P.F.; Lemson, K. Facilitating Adaptation of Biodiversity to Climate Change: A Conceptual Framework Applied to the World's Largest Mediterranean-Climate Woodland. Clim. Chang. 2012, 110, 227-248. [CrossRef]

218. Lopes, M.S.; El-Basyoni, I.; Baenziger, P.S.; Singh, S.; Royo, C.; Ozbek, K.; Aktas, H.; Ozer, E.; Ozdemir, F.; Manickavelu, A.; et al. Exploiting Genetic Diversity from Landraces in Wheat Breeding for Adaptation to Climate Change. J. Exp. Bot. 2015, 66, 3477-3486. [CrossRef]

219. Rotondi, A.; Cultrera, N.G.M.; Mariotti, R.; Baldoni, L. Genotyping and Evaluation of Local Olive Varieties of a Climatically Disfavoured Region through Molecular, Morphological and Oil Quality Parameters. Sci. Hortic. 2011, 130, 562-569. [CrossRef]

220. Enescu, V. Climate and the Choice of Seed Orchard Sites. For. Ecol. Manag. 1987, 19, 257-265. [CrossRef]

221. Lines, R. The Choice of Seed Origin by Species. In Seed Manual for Forest Trees; Forestry Commission, Forest Research Station: Surrey, UK, 1992; p. 8.

222. Carbonneau, A. The Early Selection of Grapevine Rootstocks for Resistance to Drought Conditions. Am. J. Enol. Vitic. 1985, 36, 195-198.

223. Venter, Z.S.; Jacobs, K.; Hawkins, H.-J. The Impact of Crop Rotation on Soil Microbial Diversity: A Meta-Analysis. Pedobiologia 2016, 59, 215-223. [CrossRef]

224. Pandit, N.R.; Schmidt, H.P.; Mulder, J.; Hale, S.E.; Husson, O.; Cornelissen, G. Nutrient Effect of Various Composting Methods with and without Biochar on Soil Fertility and Maize Growth. Arch. Agron. Soil Sci. 2020, 66, 250-265. [CrossRef]

225. Butterfield, J.; Bingham, S.; Savory, A. Holistic Management Handbook: Regenerating Your Land and Growing Your Profits; Island Press: Washington, DC, USA, 2019.

226. Nordborg, M. Holistic Management-A Critical Review of Allan Savory's Grazing Method; SLU/EPOK-Centre for Organic Food \& Farming \& Chalmers: Uppsala, Sweden, 2016; ISBN 978-91-576-9424-9.

227. Díaz, M.F.; Martínez, M.; Savón, L.L.; Torres, V.; Coto, G. Obtaining, Chemically Characterizing and Nutritionally Evaluating Seasonal Legume Sprouts as a Feed Alternative. In Legumes; Royal Society of Chemistry (RSC) Publishing: Cambridge, UK, 2018; Chapter 8; pp. 177-195. 
228. Oygard, R.; Vedeld, T.; Aune, J.; Starke, L. (Eds.) Good Practices in Drylands Management; The World Bank: Washington, DC, USA, 1999; ISBN 978-0-8213-4421-7.

229. Meza, F.J.; Silva, D.; Vigil, H. Climate Change Impacts on Irrigated Maize in Mediterranean Climates: Evaluation of Double Cropping as an Emerging Adaptation Alternative. Agric. Syst. 2008, 98, 21-30. [CrossRef]

230. Rahemi, A.; Yadollahi, A. Rainfed Almond Orchards in Iran-Ancient and New Methods and Value of Water Harvesting Techniques. Acta Hortic. 2006, 449-454. [CrossRef]

231. Finger, R.; Hediger, W.; Schmid, S. Irrigation as Adaptation Strategy to Climate Change-A Biophysical and Economic Appraisal for Swiss Maize Production. Clim. Chang. 2011, 105, 509-528. [CrossRef]

232. Elliott, J.; Deryng, D.; Müller, C.; Frieler, K.; Konzmann, M.; Gerten, D.; Glotter, M.; Flörke, M.; Wada, Y.; Best, N.; et al. Constraints and Potentials of Future Irrigation Water Availability on Agricultural Production under Climate Change. Proc. Natl. Acad. Sci. USA 2014, 111, 3239-3244. [CrossRef]

233. Dixon, S.J.; Sear, D.A.; Odoni, N.A.; Sykes, T.; Lane, S.N. The Effects of River Restoration on Catchment Scale Flood Risk and Flood Hydrology. Earth Surf. Process. Landf. 2016, 41, 997-1008. [CrossRef]

234. Lane, S.N. Natural Flood Management. Wires Water 2017, 4, e1211. [CrossRef]

235. Gumiero, B.; Mant, J.; Hein, T.; Elso, J.; Boz, B. Linking the Restoration of Rivers and Riparian Zones/Wetlands in Europe: Sharing Knowledge through Case Studies. Ecol. Eng. 2013, 56, 36-50. [CrossRef]

236. Martell, D.L. Forest fire management. In Handbook of Operations Research in Natural Resources; Springer: New York, NY, USA, 2007; pp. 489-509.

237. Xanthopoulos, G.; Caballero, D.; Galante, M.; Alexandrian, D.; Rigolot, E.; Marzano, R. Forest Fuels Management in Europe. In Proceedings of the Fuels Management-How to Measure Success Conference Proceedings, Portland, OR, USA, 28-30 March 2006; pp. 29-46.

238. Aquilué, N.; Fortin, M.-J.; Messier, C.; Brotons, L. The Potential of Agricultural Conversion to Shape Forest Fire Regimes in Mediterranean Landscapes. Ecosystems 2020, 23, 34-51. [CrossRef]

239. Hirsch, K.; Kafka, V.; Tymstra, C.; McAlpine, R.; Hawkes, B.; Stegehuis, H.; Quintilio, S.; Gauthier, S.; Peck, K. Fire-Smart Forest Management: A Pragmatic Approach to Sustainable Forest Management in Fire-Dominated Ecosystems. For. Chron. 2001, 77, 357-363. [CrossRef]

240. González-Olabarria, J.-R.; Pukkala, T. Integrating Fire Risk Considerations in Landscape-Level Forest Planning. For. Ecol. Manag. 2011, 261, 278-287. [CrossRef]

241. Corona, P.; Ascoli, D.; Barbati, A.; Bovio, G.; Colangelo, G.; Elia, M.; Garfi, V.; Iovino, F.; Lafortezza, R.; Leone, V. Integrated Forest Management to Prevent Wildfi Res under Mediterranean Environments. Ann. Silvic. Res. 2014, 39, 22. [CrossRef]

242. McCartney, L.; Lefsrud, M. Protected Agriculture in Extreme Environments: A Review of Controlled Environment Agriculture in Tropical, Arid, Polar, and Urban Locations. Appl. Eng. Agric. 2018, 34, 455-473. [CrossRef]

243. Neves, D. Evaluation of the protective effect of Phlomis purpurea against Phytophthora cinnamomi in Fagaceae and of Root Metabolites Involved. Ph.D. Thesis, Universidade do Algarve, Faro, Portugal, 2014.

244. Saito, S.; Kondoh, H.; Takahashi, A.; Okada, M.; Miguchi, H. Reducing Damage Caused by Oak Wilt Disease Transmitted by the Ambrosia Beetle Platypus Quercivorus (Coleoptera: Platypodidae) Using Oak Log Pile Traps. Appl. Entomol. Zool. 2016, 51, 267-274. [CrossRef]

245. Werres, S.; Wohanka, W. Filtration and Constructed Wetlands for Irrigation Water Treatment. In Biology, Detection, and Management of Plant Pathogens in Irrigation Water; The American Phytopathological Society: St. Paul, MN, USA, 2017; Chapter 19; pp. $209-233$. ISBN 978-0-89054-491-4.

246. Skees, J.R.; Barnett, B.J.; Collier, B. Agricultural Insurance Background and Context for Climate Adaptation Discussions. In Proceedings of the Prepared for the OECD Expert Workshop on Economic Aspects of Adaptation, Paris, France, 7-8 April 2008.

247. Smit, B.; Wandel, J. Adaptation, Adaptive Capacity and Vulnerability. Glob. Environ. Chang. 2006, 16, 282-292. [CrossRef]

248. Liu, X.; Wang, Y.; Peng, J.; Braimoh, A.K.; Yin, H. Assessing Vulnerability to Drought Based on Exposure, Sensitivity and Adaptive Capacity: A Case Study in Middle Inner Mongolia of China. Chin. Geogr. Sci. 2013, 23, 13-25. [CrossRef] 